DOI No: http://dx.doi.org/10.29228/Joh.54135

Authenticity process is conducted by

Makale Türü: Araştırma makalesi

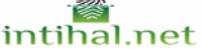

Geliş Tarihi: 09-11-2021

Kabul Tarihi: 21-12-2021

On-line Yayın: 30-12-2021

Article Type: Research article

Submitted: 09-11-2021

Accepted: 21-12-2021

Published Online: 30-12-2021

Atıf Bilgisi / Reference Information

Sunay, C., \& Tunç. B. (2021). Elli Yıl Sonra 12 Mart Muhtırasına Yeniden Bakmak. Journal of History School, 55, 3904-3936.

\title{
ELLİ YIL SONRA 12 MART MUHTIRASINA YENIDEN BAKMAK
}

\section{Cengiz SUNAY ${ }^{1} \&$ Bilal TUNÇ ${ }^{2}$}

\section{$\ddot{\mathbf{O} z}$}

Bu çalışmada analiz edilmeye çalışılacak olan: 12 Mart Muhtırası ve aslında muhtırayla bertaraf edilen 9 Mart darbe girişimidir. 9 Mart, girişimden ziyade kuvveden fiile dönüşememiş bir darbe planı olarak da isimlendirilebilir. 12 Mart Muhtırası; hem 27 Mayıs'la birlikte başlayan ordu içi hiyerarşiden sapma belirtilerine karşı, üst rütbelilerin alttan gelen tazyikle birlikte yaşadıkları kariyerist kaygı hem de 12 Mart'la birlikte orduda; dönemin yaygın tabiriyle sivil darbecilerin "çengel atılan" mensupları vasıtasıyla yönetimi ele geçirme boyutuyla incelenecektir. Altmışlı yıllar boyunca partileşen ancak kitleselleşme imkânı bulamayan; parlamentoya giren ilk yasal sosyalist partinin bir sonraki seçimde büyüyeceğine, toplum nezdinde teveccüh görmeyerek küçülmesi karşısında; iktidarı, milli güçler koalisyonunun en müessir unsuru olan ordu eliyle alma eğiliminin de incelenmesi hedeflenmektedir. Çalışmada doğal olarak 27 Mayıs Darbesi ve sonrasındaki parlamentoya geçiş öncesindeki olaylara; Aydemir İsyanlarına, Adalet Partisi iktidarının hüküm sürdüğü yıllardaki gelişmelere de 9-12 Mart süreciyle ilgisi ölçüsünde değinilmesi çalışmanın amaçları arasında yer almaktadır. Bu çalışmada doküman analizi tekniği kullanılmıştır.

Anahtar Kelimeler: 27 Mayıs, 12 Mart, Türk Solu, Gençlik

\footnotetext{
${ }^{1}$ Doç. Dr., Kocaeli Üniversitesi İktisadi ve İdari Bilimler Fakültesi, Siyaset ve Sosyal Bilimler Anabilim Dal1, cengizsunay@hotmail.com, Orcid: 0000-0001-8205-7518.

${ }^{2}$ Doç. Dr., Ağrı İbrahim Çeçen Üniversitesi Fen Edebiyat Fakültesi Tarih Ana Bilim Dalı Başkanlığ1, btunc@agri.edu.tr, Orcid: 0000-0001-5361-8494.
} 
Elli Y1l Sonra 12 Mart Muhtırasına Yeniden Bakmak

\title{
Revisiting the Memorandum of March 12th after Fifty Years
}

\begin{abstract}
What will be analyzed in this paper is the March 12 Memorandum and the March 9 coup attempt which was actually averted thanks to the memorandum. The March 9 can also be called as a coup plan, rather than an attempt, that could not be put into practice by force. The March 12 Memorandum will be examined in terms of both the careerist anxiety experienced by the higher ranks in the face of the deviation signals from the hierarchy within the army that began with the May 27 due to the pressure from the lower ranks and the seizure of power through civilian coup plotters who were "beguiled", to use the common term in that period. The paper also explores the tendency to take power through the army, which is the most effective element of the coalition of national forces against the backdrop of the representation of the first legal socialist party in the parliament which established its party organization during the sixties but unable to find the opportunity to popularize and eventually declined. As a matter of course, in the study, the events before the May 27 Coup and the subsequent parliamentary transition, the Aydemir Revolts and the developments during the rule of Adalet Partisi (Justice Party) will also be tackled to the point of their relevance to the March 9-12 process.
\end{abstract}

Keywords: The May 27 Coup, The Memorandum of March 12, Turkish Left, Turkish Youth

\section{GİRIŞ}

12 Mart Muhtırası, Türk siyasal hayatının dönüm noktalarından birisidir. Kimi kestirilemez yönleri olan, öncesi ve sonrasıyla öteden beri entelijansiyanın yalnızca, üç solcu gencin idamıyla özdeşleştirip, hüzünlü bir kahramanlık edebiyatıyla süslü ${ }^{3}$ veya aksi istikamette; vatana kastetme saikını ön plana alan ${ }^{4}$ açıklamalar, olayın arkasındaki sis perdesini daha da yoğunlaştırıyor. Hadisenin özünde sadece iç dinamiklerin olduğu istikametindeki açıklamalarla birlikte, dış dinamiklerin sadece $\mathrm{ABD}$ emperyalizmine indirgenmesi de yeterince tatmin edici

\footnotetext{
${ }^{3}$ Nihat Behram, Darağacında Üç Fidan, İstanbul: Everest Yayınları, 2005; Can Dündar, Abim Deniz [Hiç yayınlanmamış mektup ve fotoğraflarla HAMDİ GEZMISş'in anıları], İstanbul: Can Sanat Yayınları, 2014; Turhan Feyzioğlu, Deniz [Bir İsyancının İzleri],İstanbul: Su Yayınları, 2000; Turhan Feyzioğlu, Denizler ve Filistin, İstanbul: Alfa Basım Yayım, 2001; Tarkan Tufan, Deniz [Fırtınalı Yıllar], İstanbul: Nokta Kitap, 2007;Hüseyin Turhan, (Che Guevara-Deniz Gezmiş) Bir Dava İki Devrimci [Unutmak İhanettir], İstanbul: Güz Yayınlar1, 2011; Veli Y1lmaz, Emirle Gelen İdam Kararı, İstanbul: Tümzamanlar Yayıncılık, 2009; Ali Yıldırım, Deniz Gezmiş'in Günlüğü, Ankara: Yol Bilim Kültür Araştırma, 2011; Cem Çobanlı, Mahir Deniz İbo [Anlatılan senin hikayendir], İstanbul: Kalkedon Yayınları, 2008, Erdal Öz, Deniz Gezmiş Anlatıyor, İstanbul: Cem Yayınevi, 1976; Mustafa Öner, Deniz [Devrimcinin İși Devrim Yapmaktır], İstanbul: Ceylan Yayınları, 2017; Tuncay Çelen, Denizler'den Terzi Fikri'ye Türkiye, Ankara: İmge Kitabevi, 2011.

${ }^{4}$ Elverdi, 1977.
} 
olmamaktadır. Muhtıra ve sonrasındaki ara dönem hükümetlerinin kuruluş ve faaliyetlerinin ardındaki Amerikan müdahalesi ortaya konulmakla beraber, muhtırayla birlikte bertaraf edilen hükümetin, Amerikanc1 olduğu propagandasını da yine bu çevrelerin yaptığı görülmektedir ${ }^{5}$. Ortadaki açık çelişki aslında şu soruları sordurmaktadır: Amerika'nın tasfiye ettiği hükümet, Amerikancı olabilir mi? Ya istifaya mecbur birakılan hükümet Amerikanc1 değilse, onu yıpratmak için özellikle sokakta şiddet eylemleri düzenleyenlerin ${ }^{6}$ arkasındaki güç, Amerika olamaz $\mathrm{m}$ ? $\mathrm{Bu}$ durumda, bu çevrelerin dünya görüşlerinin kılavuzu konumundaki Marx'ın; o ünlü, görüntüyle öz aynı olsaydı bilim olmazdı yönündeki ${ }^{7}$ teşhisi bu olaya uyarlanacak olursa, konu hakkında yeni tezlerin ortaya atılıp sorgulanmasında yanlış olan nedir?

Kuşkusuz bu tür sorular daha önce de sorulmuş ancak soruyu ve sorulara verilen cevap denemelerine mehaz olan şahsın kimliği, cevapların tartışılmasına engel olmuş gibi duruyor. 2015 senesinde hayatını kaybeden, Milli İstihbarat Teşkilatı'nın (MITT) -kendi deyimiyle-feda ettiği Mahir Kaynak, olayların içinde, 9 Mart'ta yapılması tasarlanan darbeyi planlayan cuntalar içinde-ki bu cuntalar adeta bir koalisyon görünümündeydi- ${ }^{8}$ yer almış ve takiple görevli olduğu cuntanın muhakemesi esnasında, cuntacıların bir darbe tasarladıklarına yönelik olarak ileri sürülen iddiadaki delil yetersizliği karşısında teşkilat tarafindan deşifre edilmiş bir isimdi. Yine kendi ifadesiyle: Feda edilen Kaynak ${ }^{9}$ özellikle 28 Şubat öncesinin karmaşık doksanlı yılların başından itibaren hâkim paradigmayı sarsıcı yorumlarıyla ses getirmişti. Kaynak, soğuk savaş olarak isimlendirilen dönemle birlikte oluşturulan çift kutuplu dünya kuramından, Türkiye'nin yaşadığı askeri darbelere, Ortadoğu'daki sorunlardan NATOVarşova Paktı arasındaki gerilimlere kadar pek çok konudaki ezberi bozan ancak bozdukça itibarsızlaştırılmaya çalışılan biriydi. Adı geçen isim, kaleme aldığı ya da beyan ettiği görüşlerinde; 12 Mart öncesinde topyekûn müdahalenin radikal ancak yer yer Kemalist özellikler gösteren sol tarafından, ordu içindeki yakın unsurlar eliyle gerçekleştirilmeye çalışıldığını; bertaraf edilen 9 Mart'ın fikir cephesi itibarıyla son derece güçlü olduğunu ifadeyle, 12 Mart'ın tüm

\footnotetext{
5 Tuncay Çelen ve Ömer Gürcan, 68 Gençliği ve Katledilişi [Hesaplaşma], Ankara: Süvari Yayınc1lik, 2006, s. 281-283.

${ }^{6}$ Erol Bilbilik, Öncesi ve Sonrasiyla 9 Mart-12 Mart Süreci, Profil Yayınc1l1k, 2013, s. 15.

7 "Görünümler düzeyinde şeylerin kendilerini çoğu kez ters dönmüş şekilde ortaya koyduklarl, ekonomi politik hariç, hemen hemen bütün bilimlerde bilinen bir şeydir" (Daha Fazla bilgi için bkz. Karl Marx, Kapital [Ekonomi Politiğin Eleştirisi], (Sermayenin Üretim Süreci), Cilt 1, çev. M. Selik-N. Satligan, İstanbul: Yordam Kitap, 2015, s.515.

${ }^{8}$ Bilbilik, 2013, s.96-106.

${ }^{9}$ Mahir Kaynak, Yel Üfürdü Su Götürdü: Ailem, Çocukluğum, Gençliğim, Mesleğim, Yaşadıklarım ve Gördüklerim ...İstanbul: Babıali Kültür Yayıncılığı, 2003a, s. 22.
} 
olumsuzluğuna rağmen atlatılan bir 9 Mart'a kıyasla ehven-i şer addedilmesi gerektiğine işaret etmektedir. Bu çalışmada, 1971'den 2021'e kadar devam eden sürecin sonunda geçen elli yılın ardından 12 Mart, yeniden çözümlenmeye çalışılacaktır. Bu çalışma sonunda elde edilecek verilerin, yakın dönem Türkiye tarihi çalışmalarına yönelik bir katkı niteliğinde olabileceği düşünülmektedir.

\section{27 Mayıs'tan Devralınan Miras}

27 Mayıs darbesi, 1946'dan 1960'a kadar Türk siyasetinde etkin olan Demokrat Parti'ye karşı yapılmıştır ${ }^{10} .27$ Mayıs bir yolu açt1 ${ }^{11}$; bu yol öylesine meşru kabul edilmekteydi ki, yıllar boyu ve henüz kimi çevreler nezdinde saygınlığından hiçbir şey yitirmedi. TSK içinde bir grubun, üstelik başkumandanı

\footnotetext{
${ }^{10}$ Kemal H. Karpat, Türk Demokrasi Tarihi, (Yayın Yönetmeni: Emine Eroğlu), İstanbul: Timaş Yayınları, 2010, s.485; Eric Jan Zürcher, Modernleşen Türkiye'nin Tarihi, (Çev. Yasemin Saner), (7. Bask1), İstanbul: İletişim Yayınları, 2000, s. 295-306; Bernard Lewis, Modern Türkiye'nin Doğuşu, (Çev. Metin Kıratlı), (5. Baskı), Ankara: Türk Tarih Kurumu Yayınları, 1993, s. 306-310. 1127 Mayıs'ın birincil kaynakları: Karşılaştırmalı olarak okunmaları kaydıyla; özellikle bizzat tasarlayan yahut içinde sonradan da olsa yer alanlar ve de mağdurlarının kaleme aldıkları anılardır, bkz. Yalçın Küçük, İtirafçıların İtirafları [TKP Pişmanları], İstanbul: Tekin Yayınları, 2008; Şükran Özkaya, Adım Adım 27 Mayıs, İstanbul: İleri Yayınları, 2005; Mithat Perin, Yassiada ve İnfazların İçyüzü, İstanbul: M. Çevik Matbaası, 1970, Mithat Erin, Yassıada Faciası (27 Mayıs Darbesinden İdamlara Kadar İşkence Altında Ezilenlerin Dramı), $C-1$, İstanbul: Dem Yayınları, 1990; H. Sağıroğlu vd. Hürriyet Meşalesi [27 Mayıs Milli Türk İhtilali], İstanbul: MTTB, İstanbul Üniversitesi İktisat Fakültesi Talebe Derneği Yayınları No: 1, 1961; S1tk1 Ulay, Giderayak, İstanbul: Milliyet Yayınları, 1996; Sitkı Ulay, (General Sttkı Ulay'ın Hatıraları), “Harbiye Silâh Başına!", [27 Mayıs 1960], İstanbul: AR Matbaası, 1968; Orhan Erkanl1, Anılar... Sorunlar... Sorumlular, İstanbul: Baha Matbaası, 1973; Orhan Erkanl1, Askeri Demokrasi [Orhan Erkanlı'nın Anıları 1960-1980], İstanbul. Güneş Yayınları, 1987; Haydar Tunçkanat, 27 Mayıs 1960 Devrimi [Diktadan Demokrasiye], İstanbul: Çağdaş Yayınları, 1996; Numan Esin, Devrim ve Demokrasi [Bir 27 Mayısçının Anıları], İstanbul: Doğan Kitapçılık AŞ., 2005; Kamil Karavelioğlu, Bir Devrim İki Darbe [27 Mayıs, 12 Mart, 12 Eylül], İstanbul: Gürer Yayınları, 2007, Adnan Çelikoğlu, Bir Darbeci Subayın Anılarl [27 Mayıs Öncesi ve Sonras1], İstanbul: YKY, 2010, Ahmet Er, Hatıralarım ve Hayatım [27 Mayıs'tan 12 Eylül'e, Ahmet Yesevi'den Yunus Emre'ye], İstanbul: Pamuk Yayıncılık, 2007. Son dönem kaleme alınmış en güncel ve kapsamlı eser için bkz. Tanel Demirel, Türkiye'nin Uzun On Yllı [Demokrat Parti iktidarı ve 27 Mayıs Darbesi], İstanbul: Bilgi Üniversitesi Yayınları, 2021. Artık klasikleşmiş bir yapıtlar arasında sayılanlar: Şevket Süreyya Demir, İhtilâlin Mantığ ve 27 Mayıs İhtilali, İstanbul: Remzi Kitabevi, 1976; Şevket Süreyya Demir, Menderes'in Dramı? İstanbul: Remzi Kitabevi, (Tarihsiz), Aydemir, tarihsiz; tam bir küfürname niteliğinde. Avni Elevli, Hürriyet İçin [27 Mayıs 1960 Devrimi], Ankara: Yeni Desen Matbaası, 1961. Öğrenci olayları içindeki kimi kışkırtıcılıkların bulunduğu konusunda şüphelerini ortaya koyması bakımından: Memduh Eren, 27-28 Nisan 1960 Gençlik Eylemi Işığııda 27 Mayıs, İstanbul: Yazarın Kendi Yayını, 1996; Doğan Akyaz, Askerî Müdahalelerin Orduya Etkisi: Hiyerarşi Dışı Örgütlenmeden Emir Komuta Zinciri, İstanbul: İletişi Yayınları, 2002.
} 
konumundaki Genelkurmay Başkan ${ }^{12}$ ile Hava Kuvvetleri Kumandanın ${ }^{13}$ bile oldukça nahoş bir biçimde enterne ettiği bu kalkışma; meşruiyetini, başarısından alıyordu. Baş mağdurunun ${ }^{14}$ deyimiyle aslında; milletin lehine, egemenlerin aleyhine bozulan dengenin yeniden kurulması, fiili durumun tekrar tesis edilmesiydi ve bu açıdan şaşırtıcı bir yönü bulunmamaktayd ${ }^{15}$. İddiaya göre: İktidar 1924 Anayasasını çiğnemiş, bu nedenle meşruiyetini kaybetmişti; Türk milletinin sinesinden çıkan silahlı kuvvetler, Türk milletinin direnme hakkını kullanıyordu ${ }^{16}$. Esasında bu düşünce, 27 Mayıs 1960 darbesini gerçekleştirenlerin yaptıkları eylemi meşru gösterme eğiliminde olduklarını açık bir biçimde ortaya çıkarmaktadır.

Anayasayı çiğnemek suretiyle anayasal düzeni yeniden tesis etmek arasındaki paradoksu aşma yönünde en masum olanlar, yine bilfiil darbeyi gerçekleştiren zor gücüydü belki de. Darbenin hukuki meşruiyetini ilan noktasında olsun, son derece ölçüsüz ve yaygın tutuklamalardan cayma iradesi gösterenleri bu karardan vazgeçirmede olsun, etkin olanlar: zinde kuvvetlerin sivil kanadına mensup olanlard $1^{17}$. Yine de bizzat darbenin gerçekleştirilmesini üstlenenlerin de bundan sonra ne yapacakları konusunda mutabık kaldıkları herhangi bir programları yoktu ${ }^{18}$. Cemal Gürsel'in başkanlığında oluşturulan ve mensuplarının bir kısmı Milli Birlik Komitesi üyelerinden oluşan hükümet, tam da bu şartlarda kurulmuştu ${ }^{19}$. MBK, tamamen kendi düşüncelerini tasvip eden bir Bakanlar Kurulu oluşturmuştu. Bakanlar Kurulu listesindeki isimler incelendiğinde bu durum, açıkça görülebilmektedir ${ }^{20}$. Bu da 27 Mayıs Darbesi'ni gerçekleştirenlerin zihniyet dünyalarını ve nasıl bir amaç içerisinde olduklarını da göstermesi bakımından önem ve anlam taşımaktadır. Yine de Milli Birlik Komitesi şeklinde isimlendirilen cunta, kendi birliğini bile tesis edemedi; 27 Mayıs'tan yaklaşık beş buçuk ay sonra; 13 Kasım 1960 tarihindeki iç tasfiyeyle komitenin sözüm ona 1lımlı kanadı sözde radikal uçtaki üçte birini dışarı atmıştır. İktidarı sivillere (!) yani İnönü ve CHP’ye devrine gösterdikleri direnç,

\footnotetext{
${ }^{12}$ Org. Rüştü Erdelhun

${ }^{13}$ Org. Tekin Arıburun

${ }^{14}$ Cumhurbaşkanı Celal

15 Celal Bayar, [Anlatan], Bir Darbenin Anatomisi [27 Mayıs İhtilali], Yazan: İsmet Bozdağ, İstanbul: Emre Yayınları, 1991, s.12.

${ }^{16}$ Haydar Vural, Hürriyet Savaşımız, İstanbul: Mete Matbaası, 1960, s.147.

17 Örsan Öymen, Bir İhtilâl Daha Var... 1908-1980, İstanbul: Milliyet Yayınlar1, 1987, s.271.

${ }^{18}$ Erkanl1, 1973, s.306.

${ }^{19}$ CCA, Fon Kodu:30.18.1.2; Yer No: 155. 1. 1).

${ }^{20}$ CCA, Fon Kodu:30.1.0.0; Yer No: 54.329.2.
} 
tasfiyelerinin başlıca gerekçesi olmuştur ${ }^{21}$. Yeni komite atılanların müfritler olduklarını ilan ederken, on yıllık iktidarı boyunca anayasayı çiğnemekle suçladığı iktidar mümessillerinin atılı suçunu (!) kendi geçici anayasasını çiğneyerek işlemiştir ${ }^{22}$.

Geçici anayasa gereği, MBK üyeleri: ölüm, istifa, sürekli hastalık dışında komite üyeliğinden uzaklaştırılamıyor, yeni bir anayasayı yapmak üzere kurulacak organın tesisi için kendi içinde beşte dörtlük bir mutabakata malik olmak mecburiyetinde bulunuyorlardı (Geçici Anayasa m.9-16). ${ }^{23} 27$ Mayıs'ın ne içinde ne de dışında olmadıkları beyanında bulunanlarsa bir önceki seçimde kaydettikleri ivmenin semeresini, yapılacak acil bir seçime bağlamışlardı ve böylesi bir aceleciliği doğru bulmayan komite içindeki üyeleri ise müfrit olarak yaftalamaktan da geri durmamışlard $1^{24}$. İyi kötü belli bir dengede duran komitedeki tasfiyeler sonrası, asıl müfritlerin, Yassıada'da tabii hâkim ve olağan mahkeme prensibinden uzak sözde mahkemenin verdiği idam cezalarının infazı yönünde oy kullanacakların olduğu, kısa bir müddet sonra anlaşılmıştır ${ }^{25}$ ve TCK m.12 ihlal edilmek suretiyle İmralı'daki üç mezarın ${ }^{26}$ kazıcıları, temelli yahut daha müstehzi isimlendirmeyle: Ölesiye senatörler olarak ${ }^{27} 12$ Eylül 1980'e kadar, üstelik pek de rahat durmayarak, koltuk işgal etmişlerdir ${ }^{28}$.

Kendisine Zinde Kuvvetler diyen ve bir tür koalisyon olan zümreyi oluşturan çeşitli kesimler nazarında iktidarı kaybetmenin bedelini ödemekle geçen on yıldan alınan dersle, yeni anayasal düzene ruhunu verecek düzenlemeler, 1961 Anayasasıyla vücut bulmuştur ${ }^{29}$. Seçilmişliği oldukça

\footnotetext{
${ }^{21}$ Alparslan Türkeş, 27 Mayıs, 13 Kasım, 21 Mayıs ve Gerçekler, İstanbul: Hamle Basın Yayın, 1996, s.89.

${ }^{22}$ Muammer Taylak, 27 Mayıs ve Türkeş, İstanbul: Hamle Yayınları, 1994, s. 145;

Şu kitap, anı yazmasa da olayların içinde yer alanlarla, biri 27 Mayıs mağdurlarından birinin kızı (Nazlı Ilıcak, 15 Yll Sonra 27 Mayıs Yargılanıyor-2, İstanbul: Kervan Yayınları, 1975; Nazlı Ilıcak, 15 Yll Sonra 27 Mayls Yargllaniyor-1, İstanbul: Kervan Yayınları, 1977) diğeri ise hareketin gençlik boyutuyla temasını sağlayanlarından biri olanın oğlu (Baykam, 1994) tarafından yapılmış ilginç röportajlarla dolu.

${ }^{23}$ R. Ümit Toker, İnkılâp Mevzuatı: Teşkilâtı Esasiye Kanunu ile Tadili Hakkında Geçici Kanun [27 Mayıs 1960 Tarihinden İtibaren Vazedilen Kanunlar- Millî Birlik Komitesi Kararları Tüzükler], Ankara: Becid Basımevi, 1960, s. 26-27.

${ }^{24}$ Abdi İpekçi ve Ömer Sami Coşar, İhtilalin İçyüzü, BATEŞ Dă̆ı̆ım, 1965, s.294.

${ }^{25}$ Perin, 1970, s. 157.

${ }^{26}$ Turhan Dilligil, Imralı'da Üç Mezar, İstanbul: Dem Yayınları, 1989, s.136.

${ }^{27}$ Turhan Dilligil, (Sokaktaki Adam), Allahsız Gardiyan, Ankara: Güneş Matbaacılık, 1966.

${ }^{28}$ Esin, 2005, s167-168.

29 Orhan Aldıkaçtı, Anayasa Hukukumuzun Gelişmesi ve 1961 Anayasası, İstanbul: İ̈̈ Yayınlarından No: 1850; HF Yayınları No: 413, 1973, s. 113-133; Bülent Tanör, Osmanll-Türk Anayasal Gelişmeleri, (26. Baskı), İstanbul: Yapı Kredi Yayınları, 2006, s. 364, Bilal Tunç, Türk
} 
güçleştiren nispi temsil sisteminin tatbikiyle birlikte, temsilde adaleti öncelediklerini ifadeyle, yürütmeyi yetkiden soyutlayarak sadece bir görev olarak tanımlama, ${ }^{30}$ demokratik anlayışın istismarından başka bir şey değildi. ${ }^{31}$ Atanmışlığı anayasal ifadelerle perçinleyen, sisteme sokuşturulan Milli Güvenlik Kurulu $^{32}$ gibi organlarla vesayeti anayasal kaide altına getiren bu düzenleme; anayasaya aykırı kanunları denetleme noktasında görevli bir yüksek mahkeme daha ihdas ediyor lakin amacin kutsiyetini sorgular kılacak karar ve uygulamalarıyla yargı bürokrasisini de muhkem kılıyordu ${ }^{33}$. Yukarıda da izah olunduğu üzere 1961 Anayasası, darbeyi gerçekleştirenlerin yaptıkları eyleme bir meşruiyet kazandırma isteğinde olmuşlardır. Bu açıklamalar da, söz konusu durumu onaylamaktadır.

Toplam seçmenin yüzde 19'unun katılmayarak yüzde 38 'inin ise hayır diyerek tepki gösterdiği anayasa referandumu ve sonrasındaki parti faaliyetlerine izin dönemi de krizlerle doluydu. 1950-1960 arası uzun on yılda, önce Milli Şef'le muvazaa içinde oldukları gerekçesiyle parti liderliğine isyan bayrağı açanları $^{34}$ özellikle 1954 sonrası bizzat ana muhalefet liderine ram oluşları ilgi çekiciydi ${ }^{35}$. Üstelik yeni dönemde bu isimler kapatılan DP'nin ardılı oldukları iddiasiyla tabanda arz-1 endam bile ettiler ancak kitle, bir partiyi inandirıc1 bulmuş ve teveccühünü ona göstermiştir. EMINNSU ismiyle bilinen Emekli İnkılâp Subaylarıyla ${ }^{36}$ bir tür kader birliği içindeki eski Genelkurmay Başkanının liderliğindeki partinin 15 Ekim 1961'de yapılan seçimlerde senatoda bir, mecliste ikinci parti çıkması; yeni bir müdahalenin de gerekçesi olmuş, 21 Ekim Protokolü, milli iradenin tam olarak tecelli etmediğinden bahisle, idarenin tez zamanda milletin hakiki temsilcilerine (yani kendilerine) tevdi edileceğini imza

\footnotetext{
Anayasa Tarihinde 1961 Anayasası'nın Yeri ve Önemi, Karadeniz Araştırmaları Merkezi Dergisi, 17/67 (2020), s. 657-692.

${ }^{30}$ Anayasanın bu yönünün bir zaaf olarak değil tedbir olarak yorumlanması için bkz. Suna Kili [Ed.], 27 Mayls 1960 Devrimi Kurucu Meclis ve 1961 Anayasası, İstanbul: Boyut Kitapları, 1998. ${ }^{31}$ Ülkü Varlık ve Banu Ören, Seçim Sistemleri ve Türkiye'de Seçimler, İstanbul: Der Yayınları, 2001.

${ }^{32}$ Muharrem Balcı, MGK ve Demokrasi [Hukuk-Ordu-Siyaset], İstanbul: Yöneliş Yayınları, 1998; Mustafa Erdoğan, Silahlı Kuvvetlerin Türk Anayasa Düzeni İçerisindeki Yeri, Ankara Üniversitesi SBF Dergisi, 45/1 (1990), s.326.

${ }^{33}$ Artun Ünsal, Siyaset ve Anayasa Mahkemesi [Siyasal Sistem Teorisi Açısından Türk Anayasa Mahkemesi], Ankara: AÜSBF Yayınları No: 443, 1980, s.95.

${ }^{34}$ Samet Ağaoğlu, Siyasî Günlük, [Demokrat Partinin Kuruluşu], Yayına Haz. Cemil Koçak, İstanbul: İletişim Yayınları, 1993.

${ }^{35}$ Samet Ağaoğlu, Aşina Yüzler, İstanbul: Ağaoğlu Yayınevi, 1965.

${ }^{36}$ Kenan Esengin, 27 Mayls ve Ordudaki Klyımlar [Ordudaki Emeklilik Olay1], İstanbul: Su Yayınları, 1978, s.19-48.
} 
altına almışıır ${ }^{37}$. Esasında seçimlerden bir gün sonra Milli Birlik Komitesi, Kurucu Milli İktidar ve yetkilerinin seçimler sonunda oluşacak olan TBMM'ye devrini kararlaştırmışt $1^{38}$. Ancak bunlar yapılmadı ve MBK gücünü kaybederken Türk Silahlı Kuvvetler Birliği ismindeki yeni ve daha etkin bir cunta etkinliği ele geçirmiş̧ir. Söz konusu gelişmeler, darbe sonrası süreçte ülkenin yeniden bir kaos ortamına doğru sürüklendiğini ve yeni bir müdahale için de uygun koşulların oluşturulmaya çalışıldığını göstermektedir. Zira 12 Mart Muhtırası, bu dönemdeki karışıklıkların bir sonucu olarak tezahür etmiştir.

Oyunun kuralını koyanların, oyunda hep kazanacaklarını varsaydıkları; kazanamadıklarında ise mızıkladıklarının bariz bir örneği olan siyasal gelişmeler, Ekim 1961'den Mayıs 1963'e kadar sahnelenmiştir ${ }^{39}$. Bu süreç içinde, ünlü 5 Mart 1962 tarih ve 38 sayılı Tedbirler Kanunu gibi tavizlerle, fiili bir darbenin önlenmesi uğruna birçok ödün verilmiştir. 27 Mayıs'ın 1smarlama lideri cumhurbaşkanı, eski milli şef başbakan yapılmıştır. DP'lilerin affedilmeyeceği, EMINSU mensuplarının yeniden orduya dönemeyeceklerinin sözü alınmıştı ${ }^{40}$. İlkeden ziyade şahsiyetin öne alındığı ordu içi yeni cuntalaşmalar, buna rağmen sürmüştür. MBK kurulduğu esnada yurtdışında olanlar, yurtta olmalarına rağmen komiteye alınmayanlar; süslü anılarında devrimi (!) bizzat tasarlamasına karşın kendisini dışlanmış sayanlar hep bir firsat aradılar. Bu fırsatı bulanlardan bir grup iki kez de darbe yapmayı denediler ${ }^{41}$. İlkinde affa uğramalarıyla birlikte tek ceza olan emekliye sevklerinin caydırıcı olmadığ ikinci denemeleriyle anlaşıldı ve sonrasında da sadece ikisi idam edilmişti ${ }^{42} .27$ Mayıs atmosferinden nispi çıkış, 1965 seçimi ve neticeleriyle olmuş; 9 Mart'ta tasarlanan, 12 Mart'ta tatbik edildiği sanılan, bir müddet sonra hem 9 Martçıları hem de müstafi hükümet çevrelerini tasfiye eden sürece giden yolun taşları bu yıllarda döşenmiştir.

\footnotetext{
37 Y1lmaz Öztuna ve Ayvaz Gökdemir, Türkiye'de Askeri Müdahaleler, İstanbul: Tercüman Yayınlar1, 1987, s. 146.

${ }^{38}$ CCA, Fon Kodu:30.1.0.0; Yer No: 41.246.10.

39 Can Kaya İsen, Geliyorum Diyen İhtilal [22 Şubat-21 May1s], İstanbul: Tan Gazetesi ve Matbaası, 1977; Erdoğan Örtülü, Üç Ihtilâlin Hikâyesi, Konya: Milli Ülkü Yayınevi, 1966; Talat Aydemir, Ve Talat Aydemir Konuşuyor, İstanbul: May Yayınları, 1966; Alparslan Türkeş, 27 Mayıs, 13 Kasım, 21 Mayıs ve Gerçekler, İstanbul: Hamle Basın Yayın, 1996; Nimet Sarıül, 27 Mayls ve Talat Aydemir'in Darbe Girişimleri (22 Şubat 1962 ve 21 Mayıs 1963), [Yayımlanmamış Yüksek Lisans Tezi, Danışman: Prof. Dr. Sina Akşin], Ankara: AÜ SBE, 2001.

${ }^{40}$ Ulay, 1968, s.229-232.

${ }^{41}$ Dündar Seyhan, Gölgedeki Adam, İstanbul: Uycan Matbaas1, 1966, s.191-202.

${ }^{42}$ Ömer Gürcan, Ben İhtilâlciyim [Fethi Gürcan], Ankara: Süvari Yayınc1lık, 2005 a; Fethi Gürcan, Ömer Gürcan, Fethi Gürcan ’ın Harbiyelileri, İstanbul: İleri Yayınları, 2005b.
} 


\section{12 Mart’a Gidişin Belli Başlı Aktörleri}

25 Ekim 1961 tarihinde 306 Sayılı Milletvekili Seçim Kanunu'nun çıkarılmasından sonra 15 Ekim 1961 tarihinde seçimler yapılmıştı ${ }^{43}$. Bu arada $\mathrm{Bu}$ seçimler, diğer seçimlerden biraz farklıydı. Zira bu seçimde başta memurlar olmak üzere devlet kurumlarında çalışanların seçim propagandası yapmaları yasaklanmıştır ${ }^{44}$. Böylesine bir ortamda yapılan 1961 seçimleri sonrasındaki siyasi manzaranın ortaya koyduğu gerçek: Bir koalisyon hükümetinin kurulması istikametindeydi ${ }^{45}$. Bu düzenlemeden sonra yapılan seçimler neticesinde hiçbir parti tek başına iktidar olabilecek oyu alamamıştır. Bu da, koalisyon hükümetini zorunlu kılmıştır. Bu bağlamda, ünlü Yuvarlak Masa Toplantısının dayattı̆̆ başbakan İnönü olunca mesele, diğer koalisyon ortağının hangi parti olacağı doğrultusundaydı. Başbakan İnönü'nün kurduğu bu koalisyon kabinesinde hem milletvekillerinden hem de senatörlerden oluşan bakanlar yer almıștır ${ }^{46}$. Her ne kadar ülkenin koalisyon hükümeti tecrübesi olmasa da Batıdaki örnekler; sağın ve solun merkezindeki bir partiyle, bir başka küçük partinin bir araya gelmesi şeklindeyken, bir şekilde AP ${ }^{47}$, CHP'yle koalisyon kurma mecburiyetinde bırakılmıştır ${ }^{48}$. Amaç belki de: AP'li seçmen nezdinde, 27 Mayıs'ın siyasi kanadiyla yeni partiyi bir araya getirmek suretiyle partinin siyasal prestijine darbe vurmaktı. AP liderliği böylesi bir dayatma karşısında, en azından hükümette görev almayarak karşı hamlesini yapmış, CHP-AP koalisyonu sonrasında CHP'yle ortaklık yapan Yeni Türkiye Partisi'yle Cumhuriyetçi Köylü Millet Partisi'ndeki erime; bu öngörünün ne kadar isabetli olduğunu kısa bir zaman sonra göstermiștir ${ }^{49}$. Yani Türkiye'nin ilk koalisyon hükümetleri dönemi uzun ömürlü olamamıştır. ${ }^{50}$

1965 seçimlerine kadar ülkede tam dört hükümet kurulmuştur. Bunlardan ikisi koalisyon, ikisi de azınlık hükümetleriydi. CHP azınlık hükümeti Gümüşpala'nın vakitsiz ölümüyle boşalan AP liderliğine seçilen Süleyman Demirel marifetiyle düşürülürken, AP azınlık hükümeti bir seçim hükümeti

\footnotetext{
${ }^{43}$ CCA, Fon Kodu: 30.1.0.0; Yer No: 52.317.3.

${ }^{44}$ CCA, Fon Kodu: 51.0.0.0; Yer No: 4.33.8.

${ }^{45}$ Muzaffer Ayhan Kara, Demokrasi ve Uzlaşma Kültürü Açısından Koalisyonlar [Türk Siyasal Yaşamında 1961 Sonrası Bir Olgu], İstanbul: Otopsi Yayınları, 2014, s.53.

${ }^{46}$ CCA, Fon Kodu:30.1.0.0; Yer No: 128.819.6.

${ }^{47}$ AP hakkında hem analitik hem de betimleyici olma özellikleriyle başat bir çalışma için bkz. Tanel Demirel, Adalet Partisi [İdeoloji ve Politika], İletişim Yayınları, 2021.

${ }^{48}$ Metin Toker, İnönü'nün Son Başbakanlı̆̆ 1961-1965 [Demokrasimizin İsmet Paşalı Y1lları 1944-1973], Ankara: Bilgi Yayınevi, 1992, s. 28.

${ }^{49}$ Hikmet Özdemir, Türkiye Cumhuriyeti, İstanbul: İz Yayıncılık, 1995, s. 287.

${ }^{50}$ Söz konusu X. İnönü Hükümeti hakkında bkz. Fuat Uçar, Türk Siyasi Hayatında Azınlık Hükümetleri [İnönü ve Demirel Dönemleri], Ankara: Berikan Yayınları, 2019, s. 21-32.
} 
olarak kurulmuş ve başına da Demirel parlamenter olmadığından senatör Suat Hayri Ürgüplü getirilmiştir ${ }^{51}$. Süleyman Demirel ise bu hükümetin içerisinde Başbakan Yardımcısı ve Devlet Bakanı olarak yer almıştır' ${ }^{52}$. 12 Mart'a gidişin merhalelerinden biri olan 1965 ve 1969 seçim neticelerinin ilkinin ortaya çıkardığı iki beklenmeyen gelişme vardı. Bunlardan ilki: Milli bakiyeli, nispi temsil sisteminin bir partiye parlamentoda salt çoğunluğu sağlayacak oy barajını çok yukarıda tutmasına rağmen aldığı yüzde 53'e yakın oyla, mutlak çoğunluğun 14 fazlasiyla parlamentonun millet meclisi kanadının 240'ını elde eden AP idi ${ }^{53}$. İkincisi ise, Marksist solun Türkiye İşçi Partisi olarak seçimlere iştirak eden temsilcisi TíP'in aldığı yüzde 2,6 oyla ve kazandığı 15 sandalyeyle millet meclisinde yerini alıyor oluşuydu ${ }^{54}$. Böylece TİP, Türk siyasi tarihinde ilk defa Meclislerde temsil hakk1 elde etmiş oluyordu.

27 Mayıs'ta tasfiye edildikleri sanılanların böylesi zor bir seçim sistemine rağmen oyların yarısından fazlasını almış olması, Zinde Kuvvetler nezdinde tam anlamıla şok etkisi yaratmıştı ${ }^{55} .27$ Mayıs'ta TSK eliyle direnme hakkını kullanan millet söyleminin gerçekdışı olduğu böylece tescil edilmiş oluyordu ${ }^{56}$. Marksist sol ise bütün dağınıklığına rağmen, 27 Mayıs sonrasının sağladığı özgürlükler eşliğinde ilk kez seçimlere giriş müsaadesi almış ve yurt sathında 300.000 oya ulaşmış olmayı, geçirilecek bir seçim devresi sonunda çok daha yukarılara çekme noktasında bilenmiş, yine de temkinli olmayı elden bırakmama yönünde, özellikle parti yönetiminin tembihleri doğrultusunda hareket etme kararl1lı̆ğndayd ${ }^{57}$.

12 Mart'ın doğrudan hedef aldığı AP ve TiP ile her ikisi kadar tehlikeli görülmediği Milli Selamet Partisi ismiyle yeniden kurularak 1973 seçimlerine iştirak etmesine müsaade, hatta teşvik edildiği iddia edilen ${ }^{58}$ Milli Nizam Partisi geleneği bu süreci nasıl geçirdiler? MNP 1970 başlarında siyaset sahnesine çıkması sebebiyle bir tarafa bırakılırsa; AP ve TIP'in 12 Mart Muhtırası sonrasındaki gelişmelerdeki dahli, kurumsal kimliklerinin çok ötesindeymiş gibi gözüküyor. AP, DP'nin mirasına talip ancak eski DP kadroları nezdinde emanetçi

\footnotetext{
51 Türker Sanal, Türkiye Cumhuriyeti ve 50 Hükümeti, Sim Matbaac1lık, 1995, s. 46.

${ }^{52}$ CCA, Fon Kodu:30.1.0.0; Yer No: 54.329.6.

53 Özdemir Kalpakçıŏlu, İkinci Cumhuriyetin 3 Başbakanı ve Olaylar-III [İnönü-ÜrgüplüDemirel], Ankara: Nüve Matbaası, 1969, s. 7.

${ }^{54}$ Mehmet Ali Aybar, Türkiye Iş̧̧̧i Partisi Tarihi, Yay. Haz. Kıvanç Koçak, İstanbul: İletişim Yayınlar1, 2014, s. 243.

${ }^{55}$ Kurtul Altuğ, 27 Mayls'tan 12 Mart'a, İstanbul: Koza Yayınları, 1976, s. 373.

${ }^{56}$ Hikmet Özdemir, Türkiye Cumhuriyeti'nde Rejim ve Asker İlişkisi Üzerine Bir İnceleme, İstanbul: İz Yayınc1lik, 1993, s.121.

${ }^{57}$ Sadun Aren, TIP Olayl [1961-1971], İstanbul: Cem Yayınevi, 1993, s.105.

${ }^{58}$ Soner Yalçın, Hangi Erbakan, Ankara: Başak Yayınları, 1994, s. 67
} 
konumundadır ve bundan da başta Demirel olmak üzere parti eliti oldukça rahatsızdır ${ }^{59}$. Yuvarlak Masa toplantısının üzerinden geçen yıllar içinde, önce cezaevlerinden tahliye edilen ardından hem siyasi haklarının hem de itibarlarının iadesini talep eden Celal Bayar öncülüğündeki DP'li elit, Demirel'in İnönü ve TSK'yı kasten umacı gibi gösterip söz konusu yasakları örtülü olarak desteklediği kanaatindedirler. Nitekim İnönü’nün; kendisi gerekçe gösterilmek suretiyle böylesi bir hamleden beri duran Demirel'in elindeki kozu bertaraf eden beyanatı sonrası girişilen anayasa değişikliği girişimi, az kalsın bir askeri darbeye sebep olacakt $^{60}$.

AP'de temsil imkânı bulan sermayenin boyutları itibarıyla tasnif edilen bileşimi içindeki çatlak ise artık bir bölünmenin yaklaştığını ortaya koyuyordu. Bütün iktidar imkânlarının sanayi sermayesine peşkeş çekildiği iddiasını gündeme getiren çevrelerin örgütsel ifadesi olan çeşitli oda temsilcilerinin sözcüsü konumundaki isimler çok sert ve parti disipliniyle hiç de bağdaşmayan bir çıkış yaparak hükümet bütçesine ret oyu vermişlerdir ${ }^{61}$. Bu hamle, ismiyle aslında hakiki halefin kim olduğunu işaret edercesine Demokratik Parti etrafindaki kopuşun işaret fişeğiydi aslında. 12 Mart'a uygun zeminin sağdaki boyutu böylesi bir bölünmenin yarattığı zafiyetin gölgesinde oluşmuştur.

TIP ise tam anlamıla ikili bir sıkıştırma içindeydi; bir taraftan parti içinde yoğun bir şekilde metot tartışmaları yapılmış, parti yönetiminin burjuva düzeninin hukukuna olan riayeti hiç de devrimci bulunmamıştır. Partinin olası bir kapatma karşısındaki temkinli tutumu bir zafiyet belirtisi olarak takdim edilmiştir. Esasında ülke genelinde TỉP'e karşı bir olumsuz algının olduğu anlaşılmaktadır. Bu da, TìP Genel Başkanı Mehmet Ali Aybar'ın 5 Temmuz 1965 tarihinde, Bursa' da söz konusu partililere yönelik olarak yapılan olumsuz hareketlere karşı, yapmış olduğu basın toplantısında açıkça ortaya çıkmaktadır ${ }^{62}$.

1965 seçimleri sonrasındaki yoğun parlamento içi ve dişı muhalefet dalgasının 1969 seçimlerinde belirleyici olacağı ve sosyalizmin olası bir TïP iktidarılyla seçimle gelebileceği doğrultusundaki beklenti komik ve ütopik

\footnotetext{
${ }^{59}$ Mehmet Turgut, Siyasetten Portreler, İstanbul: Boğaziçi Yayınları, 1990.

${ }^{60}$ Sadettin Bilgiç, Hatıralar, İstanbul: Boğaziçi Yayınları, 2002, s.185-191.

6112 Mart'ın ekonomi politiği konusundaki çalışmaların ana tezi bu istikamettedir: Sermaye çevreleri arasındaki rekabet ve bu rekabetin AP içindeki koalisyonun bozulmasına kadar gidecek ölçüde uzlaşılamaz boyuta gelişi. Konu hakkındaki ayrıntılı okuma için bkz. Ahmet Aker, 12 Mart Döneminde Dışa Bağımlı Tekelleşme, İstanbul: Sander Yayınları, 1975; Ergin Eroğlu, 12 Mart Devam Ediyor mu? İstanbul: Soyut Yayınları, 1994; Ali Gevgilili, Yükseliş ve Düşüş, İstanbul: Altın Kitaplar Yayınları, 1991; Ali Gevgilili, Türkiye'de Kapitalizmin Gelişmesi ve Sosyal Sınıflar, İstanbul: Bağlam Yayınları, 1989.

${ }^{62}$ CCA, Fon Kodu:30.1.0.0; Yer No: 48.284.2.
} 
bulunmuştur ${ }^{63}$. Lokomotifi Doğan Avcıoğlu olan YÖN Hareketi'nin adeta siyasi partiler kanununa ve Anayasa Mahkemesi denetimine tabi olmayan bir siyasal parti gibi hem rejime hem de TİP'e hücum edişi, 1969 seçimleri hezimetiyle birlikte partiyi tam anlamıyla çöküşe sürüklemiştir ${ }^{64}$. 1969 seçimleri öncesinde radyoda TiP adına bir konuşma yapan Tarık Ziya Ekinci, 1965 seçimlerinde olduğu gibi bu seçimlerde de başarı elde edeceklerini tahmin ediyordu ${ }^{65}$. Ancak sonuç beklendiği gibi olmadı ve seçim TİP için bir zaferden ziyade hezimete dönüştü. Hele daha bir yıl öncesinde Genel Başkan Mehmet Ali Aybar'ın düşlenen sosyalizmi, adeta dönemin reel sosyalizmine gönderme yaparcasına güleryüzlü olacağı şeklindeki takdimi, 1968 Prag Baharına yönelik Sovyet müdahalesine eleştirel yaklaşımı, çatıda da derin bir çatlak yaratmışıır ${ }^{66}$. Esasında 1965 seçimlerinden sonra Tï, Türkiye'de yapılan hiçbir seçimde istediği neticeyi elde edememiştir. Bu da seçmen tarafından henüz TïP gibi görece 1lımlı Marksist bir partiye bile temayül edilmediğini göstermektedir.

\section{9 Martçıların Yenilgisi ve 12 Mart'ın Niteliği}

Türkiye devriminin proletarya tarafından mı, yoksa ülkenin kendi tarihsel deviniminin ortaya çıkardığı gelişme doğrultusunda oluşmuş, emperyalizmin boyunduruğu altında ezilme noktasındaki ortak paydaya sahip diğer sınıflarla iş birliğiyle mi yapılacağı altmışlı yılların, solda bölünme yaratan tartışma konularının başında gelmiştir ${ }^{67}$. İşçi sınıfının öncülüğünü tartışmayı bile sosyalizmden sapma olarak gören Marksistler, 1968 eylemleriyle birlikte, gençlik; daha doğru bir ifadeyle, devrimci gençlik olarak nitelendirilen yeni bir gücün aktif katılımıla birlikte, nihayetinde 1969 seçim sonuçlarının TíP'in hiç de beklenildiği hamleyi yapamadığı gerçeğiyle yüz yüze geldiklerinde, süreç artık yeni bir aşamaya tekâmül etmeye başlamıştır ${ }^{68}$.

Altmışlı yıllar, Türkiye Solu açısından ilginç özelliklerle yoğun ideolojik ve pratik dönüşümlerin yaşandığı yıllardı. İkinci Meşrutiyet'le yaşıt, oldukça semereli birikime sahip olmasına rağmen beynelmilel komünizmin aşırı

\footnotetext{
${ }^{63}$ Mustafa Şener, Türkiye Solunda Üç Tarz-ı Siyaset [Yön, MDD ve TİP], İstanbul: Yordam Kitap, 2015.

${ }^{64}$ Hikmet Özdemir, Sol Kemalizm, İstanbul: İz Yayıncılık, 1993; Muzaffer Ayhan Kara, Yön'ün Devrimi Devrim 'in Yönü, İstanbul: Cumhuriyet Kitapları, 2008.

${ }^{65}$ CCA, Fon Kodu:30.1.0.0; Yer No: 48.284.3.

${ }^{66}$ Mehmet Ali Aybar, Neden Sosyalizm [Bir Son Sözle], İstanbul: BDS Yayınları, 1987.

67 Çetin Yetkin, Türkiye'de Soldaki Bölünmeler 1960-1970 [Tartışmalar, Nedenler, Çözüm Önerileri], Ankara: Toplum Yayınları, 1970, s.13-79.

${ }^{68}$ Çetin Yetkin, 12 Mart 1971 Öncesinde Türkiye'de Soldaki Bölünmeler, İstanbul: Toplumsal Dönüşüm Yayınları, 1998.
} 
merkeziyetçiliğinin gölgesinden çıkamayan Türk solu, Türkiye'nin şartlarına içeriden ve yerli teşhis ve çözüm önerileri getirmede oldukça başarısız olmuştu ${ }^{69}$. Millî Mücadele esnasında bir takım solumsu (!) denebilecek örgütler, 1920 Eylül'ünde Bakü'de toplanan Doğu Halkları Kurultayı'na ruhunu veren Sovyet devletinin iç ve dış politik hassasiyetinin mahsulü olan tezler eşliğinde, Türk hükümetinin niteliği konusundaki algısını bir türlü netleştirememiş, Türk-Sovyet ilişkilerinin genellikle olumlu sayllabilecek seyrine göre belirlediği tutumuyla özdeş bir öngörüsüzlük içinde sürüklenip durmuştu ${ }^{70}$. Türkiye'de yönetici elitle üretici sınıflar, üretim ilişkilerinin biçimi ve bu noktada komünistlerin tutumu ne olmalıdır, şeklindeki suallere verilen cevaplardaki çeşitlilik ise dar ve sinırlı kadrolarındaki bölünmenin baş sebeplerinden biri olmuştu ${ }^{71} 1925$ ve 1951 Tevkifatları, hareketi sınırlı sayıda iç, yoğun olarak dışarı odaklı bir örgütlenmeye mecbur k1lmışt ${ }^{72}$. Hele bir kısım kadrolarının Kemalizm'e gönüllü ilticaları da gerçekleşince ${ }^{73}$, 27 Mayıs öncesine kadar kimin sosyalist, kimin Kemalist olduğu noktasındaki çizginin berraklığını da tespit etmek oldukça güçleşmişti.

Altmışlı yıllar sol radikalizmin ürettiği şiddet söylemleri sonucu Türkiye'de çeşitli olaylara sahne olmuştur. 1968'in Mayıs ayında Avrupa'da görülen "kampüsleri ele geçirme" eylemlerine benzer bir şekilde Türkiye'de ilk ciddi üniversite işgalleri başlamış ve 12 Haziran 1968'de İstanbul Üniversitesi Rektörlüğü üç hafta süreyle işgal edilmiştir. ${ }^{74} \mathrm{Bu}$ şekilde Altmışlı yılların başlarında da bulanıklık sürmekte, Doğan Avcıoğlu'nun mihmandarlığındaki YÖN Hareketinin, Millî Mücadelenin niteliği konusundaki açlımı ve antiemperyalizmin ${ }^{75}$ Kemalizm'in özü ve esası olduğu yönündeki telkini de etkili olunca, solun bir taraftan sol ve özgün kalma kaygısıyla, diğer taraftan kitleselleşmeye uygun bir kapsayıcılığı da gözeten, tabanda önemli bir güç olan Kemalist eğilimleri toparlayıcı teorik revizyonlar yapması kaçınılmaz olmuştur ${ }^{76}$.

${ }^{69}$ George S. Harris, Türkiye'de Komünizmin Kaynakları, çev. Enis Yedek, İstanbul: Boğaziçi Yayınlar1, 1979.

70 İlhan Akdere ve Zeynep Karadeniz, Türkiye Solunun Eleştirel Tarihi-1, İstanbul: Evrensel Basım Yayım, 1994, s.114-120.

${ }^{71}$ Vehbi Ersan, 1970'lerde Türkiye Solu, İstanbul: İletişim Yayınları, 2014, s.17-21.

${ }^{72}$ Sevim Belli, Boşuna mı Çiğnedik? [Anılar], İstanbul: Belge Yayınları, 1994, s.288-290.

${ }^{73}$ Sami Küçük, Rumeli'den 27 Mayıs'a [İhtilalin Kaderini Belirleyen Köşk Harekâtı], İstanbul: Mikado Yayınları, 1988, s. 23-57.

${ }^{74}$ Fuat Uçar, Türk Siyasi Hayatında Milliyetçi Cephe Hükümetleri, 2. Bask1, Ankara: Berikan Yayınevi, 2021, s. 118.

${ }^{75} \mathrm{Bu}$ polemikteki en önemli isimlerden biri de Hikmet Kıvılcımlı'dır, bkz. Hikmet Kıvılcımlı, 27 Mayıs ve Yön Hareketinin Sinıfsal Eleştirisi, İstanbul: Ant Yayınları, 1970.

${ }^{76}$ Gökhan Atılgan, Yön-Devrim Hareketi [Kemalizm ile Marksizm Arasında Geleneksel Aydınlar], İstanbul: TÜSTAV, 2002, s.113-122. 
Hedef artık salt işçi sınıfının iktidarı olmaktan çıkmış, iktidara en kolay ve hızlı nasıl ulaşı1ır, bu hedefi elde etme doğrultusundaki en kestirme yöntem hangisidir noktasındaydı. YÖN de adeta rakip bir siyasal partiymişçesine, TİP'in sistemin kuralları içinde mücadele etmek suretiyle parlamenter usullerle iktidara gelmeyi programının esasına yerleştirmesinin ütopik aldatıcılığına eleştiriler yaparken ${ }^{77}$, genç tabanda 1969 seçim neticelerinin ortaya koyduğu tablonun, bir süredir TIP'in istikbali konusundaki umutlu bekleyişi de hayal kırıklığına dönüştürdüğü gözlemlenmiştir.

Fikir Kulüpleri Federasyonu'nun Devrimci Gençlik Federasyonu'na dönüşmesi ${ }^{78}$ bir isim değişikliğinin çok ötesindeydi. Gençlik içindeki öncü kesimler, Avcıoğlu'nun teşhisiyle hemfikirdiler artık, böylesi sosyoekonomik düzen devam ettiği müddetçe sandıktan hep gerici (!) partilerin çıkacağını, düzen içinde çözüm arayışı içinde olmanın tam manada havanda su dövmekten farksız olacağ 1 hususunda birleşmişlerdir ${ }^{79}$. Yine de bu kanaat, kendi aralarında bölünmelerine engel olmadi; 12 Mart veya onun bertaraf ettiği 9 Mart öncesinde, gençlik eylemleri henüz özerk silahlı mücadele boyutuna gelmemişti. Üniversitelerde işgal ve boykotlar, ABD emperyalizminin sembolik unsurlarına yönelik eylemlerin ötesine henüz geçmemişti ${ }^{80} .16$ Şubat 1969 olayları, Taylan Özgür ve Vedat Demircioğlu'nun katli gibi hadiseler ${ }^{81}$, aslında memleketi peyk devletlerden biri yapma amacının dahili hamleleri olarak yorumlanınca, sağ sivil inisiyatif de yeni bir hasım olarak ortaya çıkmıştır.

9 Mart olayının aktörleri bu kesimlerle aralarında olan ideolojik kimi yakınlıklara rağmen tamamen farklı bir metot dairesinde çalışıyorlardı. Türkiye'nin modernleşme tarihinde en öncü ve ilerici kurumu olarak gördükleri ordunun ve ordu içi sol unsurların gerçekleştirecekleri ilerici bir darbeyle iktidarı ele geçirip, mevcut düzenin ideolojik aygitları vasıtasıyla biçimlendirdiği toplumsal ve siyasal kültürü aksi istikamette dönüştürmeyi hedeflemişlerdir ${ }^{82}$. Ağırlıklı olarak 27 Mayıs'ın kaçırılmış bir firsat olarak görülmesi, yine de ders alınacak bir numune olarak 27 Mayıs'ın bir tür yarım kalmış devrim olduğu kanısının hâkim olduğu gözlemleniyor; her ne kadar zor gücü olarak silahlı

\footnotetext{
77 Ergün Aydınoğlu, Türk Solu [Eleştirel Bir Tarih Denemesi 1960-1971], İstanbul: Belge Yayınlar1, 1992, s.38-45.

78 Ali Yıldırım, FKF Dev-Genç Tarihi [1964-1971 belgeleriyle bir dönemin serüveni], İstanbul: Doruk Yayınları, 2008; Turhan Feyzioğlu, FKF Fikir Kulüpleri Federasyonu [Demokrasi Mücadelesinde Sosyalist Bir Öğrenci Hareketi], İstanbul: Ozan Yayıncılık, 2015.

${ }^{79}$ Doğan Avcioğlu, Devrim Üzerine, Ankara: Bilgi Yayınevi, 1971, s. 192-193.

${ }^{80}$ Harun Karadeniz, Olaylı Yıllar ve Gençlik, İstanbul: May Yayınları, 1975, s.240-249.

${ }^{81}$ Mehmet Bican, Devrim Iç̧in Gençlik Hareketleri, Ankara: Güvendi Matbaası, 1970, s.60.

${ }^{82}$ Mihri Belli, Milli Demokratik Devrim, İstanbul: Aydınlık Yayınları, 1966, s. 33-34.
} 
kuvvetlerin ve onun kimi unsurlarının isimleri ön plana çıssa da aslında perdenin bir parça arkasında olmakla birlikte asıl önde olanlar sivillerdi.

Doğan Avcıŏlu, İlhan Selçuk, İlhami Soysal, Cemal Madanoğlu, Fakih Özfakih, Numan Esin, İrfan Solmazer, isimleri o dönemde böylesi yapılanmalarda sıkça geçenlerin önde gelenleriydi. Madanoğlu, Esin ve Solmazer eski Milli Birlikçiler olarak temayüz ederken; ilki diğer ikisini 13 Kasım 1960'ta tasfiye eden ekibin de önde gelenidir ${ }^{83}$. Tabandaki sol dalgadan görece bağımsız, asıl hedefin ordunun dinamik unsurları eliyle yapılacak bir topyekûn askeri darbeyle yönetimi ele geçirip dar bir kadroyla hızlı kalkınmanın reçetelerini tatbik etmek olan bir hareket, özellikle hiç de sır olmayan bu hedefini haftalık Devrim Gazetesinde sıkça işliyor, cari demokratik düzeni; sandıksal, cici ve Filipin demokrasisi yaftalarıyla küçümsüyordu ${ }^{84}$. Sivil ve emekli askerlerden oluşan bu grubun temel hedefi: Ordu içi önemli görevlerde bulunan ve kendi dünya görüşlerine yakın olan subaylarla temasa geçmek ve Türk ordu geleneğine vakıf olan biri için tahmini çok kolay olan muhtemel cuntalarla ilişki kurmaktı. Nitekim böylesi gruplaşmalar, çeşitli kara, hava ve deniz birliklerinde mevcuttu ${ }^{85}$. Tabandaki küçük rütbeli subayların daha kalabalık olduğu bir piramide benzer yapının temayüz etmiş isimleri bulunuyordu. Celil Gürkan ${ }^{86}$, Şükrü Köseoğlu, Vedii Bilget, Necdet Gürkan, Mehmet Tuğcu, M. Ali Akar, Ömer Çokgör; bu isimlerin hem rütbece önde hem de en aktifleriydi. Ordu geleneğinde albayların yeri ve önemi biliniyor; hareketin önde gelen albay rütbeli elemanları ise: Bahattin Tatar, Nedim Arat, Mehmet Namlı, Kadir Ol, Ömer Şamlı gibi isimlerdi ${ }^{87}$.

Türk ordusunun emir-komuta zinciri içinde hiyerarşiye bağlılığıyla kimi zaman tezat teşkil eden müdahale eğilimiyle birlikte, yine de girişilecek darbede birlik ve bütünlüğü sağlamada çok önemli olan, görünüşte de olsa harekâtın en tepesine 27 Mayıs tabiriyle: Omzu kalabalık bir baş bulmak tutkusu, 9 Mart'1 da sonu hüsran olacak neticeye itmişti. Celil Gürkan bir tümgeneraldi, Vedii Bilget de tümamiral; diğer isimler ise tuğgeneral rütbelerini taşıyorlardı. 9 Mart'ın

\footnotetext{
83 Cevdet Sunay, 27 Mayıs'tan 13 Kasım'a Milli Birlik Komitesi, Ohri: Social and Cultural Integration in Balkans, International Vision University, 2017, s.157-166.

${ }^{84}$ Hasan Cemal, Kimse Kızmasın Kendimi Yazdım, İstanbul: Doğan Kitap, 1999, s.278.

85 Orhan Savaşçı, Cepheden Anılar [Orhan Savaşçı'nın THKP-C Anıları], İstanbul: Ayrıntı Yayınlar1, 2015, s.19-21.

869 Mart'ın en gözde askeri sayılan Gürkan'ın, (Muhsin Batur, Anılar ve Görüşler, [Üç Dönemin Perde Arkas1], İstanbul: Milliyet Yayınları, 1985) tarafından kaleme alınan hatıralarına adeta cevap niteliğindeki anıları çok önemlidir: Gürkan, 1986. Bu isimlerin pek çoğuyla, bir belgesel için yapılıp kitaplaştırılmış röportajlar için bkz. Biran vd., 1994.

${ }_{87}$ Nazlı Ilıcak,12 Mart Cuntaları [Demokrasinin Sırtındaki Hançer] İstanbul: TİMAŞ Yayınları, 2001, s.196.
} 
rütbece düşük ancak önemli isimlerinden biri olan Erol Bilbilik denizci binbaşıydı; tabandaki en düşük rütbeli iki subay olarak öne çıkan Sarp Kuray ve Ali Kırca ise henüz birer teğmendiler ${ }^{88}$. 27 Mayıs'taki Gürsel modeli içinde düşünüldükleri ve sonunda önce etkisizleştirilip sonrasında tasfiye edilecekleri endişesi de tavandaki iki isme: 12 Mart Muhtırasından sonra 1972 yllında Genelkurmay Başkanlığına getirilen dönemin Kara Kuvvetleri Komutanı Org. Faruk Gürler ${ }^{89}$ ve Hava Kuvvetleri Komutanı Org. Muhsin Batur'a; 9 Mart gibi radikal bir darbe yerine 12 Mart gibi hem tabandaki tazyiki yumuşatan ve hükümete karşı bir şey yapıldığı noktasında asgari tatmini hem de 9 Martçı radikal grubun tasfiyesini sağlayan hamleyi yaptırmıştı denilebilir.

\section{12 Mart'ın Meșruiyet Gerekçeleri Haklı mıydı?}

12 Mart'ın asıl gerekçesinin; aslında 21 Ekim 1961 'de, 15 Ekim seçim sonuçlarının yarattığı şok üzerine Silahlı Kuvvetler Birliği Cuntasının, İstanbul ve Ankara grupları tarafından imza altına alınan protokolde gizli olduğu söylenebilir. Söz konusu protokol metninde örtülü olarak, 27 Mayıs' $1 n^{90}$ arkasında olan gücün, yani CHP'nin aldığı oyun azlığı karşısında seçmene karşı duyulan öfke yatmaktaydı ${ }^{91} .1961$ Anayasa oylamasında çıkan sonuç, doğrusu 15 Ekim seçim neticelerinin akıbetine dair önceden bir işaret fişeği de yakmışt1; yine de 1957 seçimlerinde yüzde 40'1 aşmış bir CHP'nin tek başına iktidara geleceği konusundaki tereddüt, oldukça azd1. Hatta İnönü'nün bile Faik Ahmet Barutçu'yu vasita k1larak kendisine ulaşan darbecilere "böyle şeylere karışmasınlar, CHP seçimi mutlaka kazanacaktır" dediği rivayet edilir. Yeni anayasanın yürütmeyi pasif kılarken çeşitli özerk kurumlar ihdas eden doğası, üst kurullar yoluyla seçimden galip çıkan partinin meşrebine göre denetimi veya desteklenmesi, bir de üstüne üstlük seçim sistemiyle birlikte tek bir partinin; hele CHP'nin iktidar olma olasılığını oldukça zayıflatmıştı ${ }^{92}$. Amaç: Güçlü bir CHP iktidarından ziyade, 1965 seçimlerinde de görüldüğü gibi gelmesi pek muhtemel bir muhafazakâr sağ iktidarı frenleyecek anayasal mekanizmalar kurmaktı. Nitekim sonu 12 Eylül'e kadar gidecek bu tür mekanizmalar, 12 Mart sonrası yapılan anayasal düzenlemelerle daha da güçlendirildi. Muhtıranın tam metni

\footnotetext{
${ }^{88}$ Sarp Kuray, İsyan ve Tevekkül, İstanbul: Birharf Yayınları, 2008,s.36.

${ }^{89}$ CCA, Fon Kodu:30.18.2.2; Yer No: 286.62.6.

${ }^{90}$ İki darbe arasındaki illiyet için en iyi analizlerden biri şu kitapta yapılmaktadır: Kurtuluş Kayalı, Ordu ve Siyaset [27 Mayıs-12 Mart], İstanbul: İletişim Yayınları, 1994.

${ }^{91}$ Aydemir, 1966, s.106-109

${ }^{92}$ Bülent Tanör, İki Anayasa [1961 ve 1982], İstanbul: Beta, 1994: 28.
} 
üzerinden yapılacak kısa bir değerlendirme, aslında meşruiyet gerekçelerinin de temelsizliğini gösterecektir.

12 Mart Muhtırası tabii ki işbaşındaki hükümete hitaben yazılmışt1 ${ }^{93}$ ancak uygulamalarına ve başlangıçta destek gördüğü kesimlere yönelik icraatına bakıldığında; hasım bellediklerinin profili oldukça geniş, hasımlarının ABD'yle olan mesafesi de oldukça uzaktı. Bu yönüyle muhtıranın, içeriğindeki gerçeklerle bağdaşmayan iddialar ve çözümü ihmal edilmiş meselelerdeki sorumluluk payını sadece sivillere hamletme eğilimi üzerinde kısaca durulması gerekiyor. Her şeyden önce, özellikle 27 Mayıs sonrasında egemenliğin tamamının CHP+Ordu= İktidar, olmazsa ihtilal denkleminde yürüdügü, sadece İnönü ve partisi aleyhine meydana gelen iki askeri darbe girişimi karşısında sivil yönetimin arkasında olunduğu mesajı verildiği biliniyor. 1961-1965 yılları arasında 27 Mayıs fikriyatının egemen olmasına rağmen ve anayasanın öngördüğü reformların tatbikine yönelik fırsatların heba edildiği de açıkmış gibi duruyor. Oysa 1965 'te iktidara gelen ve iktidarının hayatiyetini silahlı güçleri ürkütmemek üzere son derece dikkatli olmakla icraat yapmak arasındaki hassas noktayı gözetmek zorunda olan AP hükümetlerinin geçen altı yılda kazandığı pek çok genel ve ara seçime rağmen diken üstünde oluşunun hiç de altı çizilmemiştir ${ }^{44}$.

Altında dört kumandanın imzası olmasına rağmen ve bunlardan sadece ikisinin imzasının gönüllü, diğer ikisinin ise kerhen atıldığ bilinen, üç maddelik bir ihtarname niteliğindeki muhtıranın ${ }^{95}$ ilk maddesi:

Meclis ve hükümet, süregelen tutum, görüş ve
icraatlarıla yurdumuzu anarşi, kardeş kavgası,
sosyal ve ekonomik huzursuzluklar içine sokmuş,
Atatürk'ün bize hedef verdiği uygarlı seviyesine
ulaşmak ümidini kamuoyunda yitirmiş ve
anayasanın öngördügüu reformları tahakkuk
ettirememiş olup, Türkiye Cumhuriyeti'nin
geleceği ağır bir tehlike içine düşürülmüştür.

Şeklindeydi ve hedefinde parlamento ve hükümet olduğu kanaati hakimdi. Oysa geçen altı yıl içinde belli başlı kriz konuları ise birkaç başlıktan ibaretti. TïP

\footnotetext{
${ }^{93}$ Feroz Ahmad, Demokrasi Sürecinde Türkiye, 1945-1980, (Çev. Ahmet Fethi), İstanbul: Hil Yayınları, 1996, s. 353-356; Tevfik Çavdar, Türkiye'nin Demokrasi Tarihi 1950'den Günümüze, (5. Bask1), Ankara: İmge Kitabevi, 2013, s.191.

${ }^{94}$ Meseleyi tam da bu sorunsal ekseninde inceleyen şu çalışma çok önemlidir: bkz. Ümit Cizre, $A P$ Ordu İlişkileri [Bir İkilemin Anatomisi], İstanbul: İletişim Yayınları, 1994; William Hale, Türkiye'de Ordu ve Siyaset 1789'dan Günümüze, (Çev. Ahmet Fethi), Hil Yayınları, 1996.

${ }^{95}$ Hüseyin Demirel, 12 Mart'ın İçyüzü [Nasıl Geldi, Nasıl Geçti?], İstanbul: Yeni Asya Yayınları, 1977, s.119-120.
} 
ülkedeki NATO üslerinin 35 milyon metre karelik alanın işgali anlamına geldiği propagandasını yapıyor ${ }^{96}$; 35 kilometre kareyi metre kareye çevirerek algı1 görünür kılmak istiyordu. Muhtıracılarla TíP tezleri arasında bir yakınlık kurmak mümkün gözükmüyordu, demek ki bu noktada hükümetle hemfikirdiler.

Asıl kriz CHP içinde, seçim yenilgisinin partinin ortanın solundaki konumuyla alakası üzerine parti içi bir tartışma şeklindeydi ve sonu; partiden iki ayrı partinin, gelecekte birleşmek üzere kopuşuyla sonuçlanmıştır. AP, DP'nin üzerine çektiği askeri muhalefetin sebeplerinden biri olan askerlerin ekonomik problemlerini çözmek üzere yüksek maaş ve lojman temin edecek, maddi durumlarını daha iyileştirecek olan Askeri Personel Kanunu tasarısı bile hazırladı. Üniversitelerdeki işgal ve boykotlar hükümetten değil asıl, muhalefetten destek görüyordu ve bu esnada yaşanan kimi şiddet eylemleri anayasanın verdiği hakların kullanılması olarak yorumlanıyor, hükümet de her firsatta bu durumdan müşteki olduğunu ifade ediyordu. Üstelik çap1, Avrupa ülkelerindekine göre oldukça düşüktü̈ ${ }^{97}$.

16 Şubat 1969 tarihli Kanlı Pazar Olayı da üzüntü verici olmasına rağmen son derece lokal bir eylemdi ve dünyanın o günkü durumunda benzerleri pek çok ülkede meydana gelmekteydi. DISSK'i TÜRK-İş karşısında zayıf kılacak 274 Sayılı Sendikalar ile 275 Sayılı Toplu İş Sözleşmesi, Grev ve Lokavt Kanunundaki değişikliklere tepki olarak meydana gelen 15-16 Haziran 1970 tarihli Büyük İşçi Yürüyüşü ve ardından gelişen şiddet olaylarında sorumluluk payı, hükümetle birlikte muktedirler cephesindeki diğer unsurlara da aitti ${ }^{98} .1965$ 1971 yılları arasındaki ekonomik göstergeler 1961-1965 yılları arasındaki durağanlığın ortadan kalktığını gösterir nitelikteydi. Türkiye adeta 1950-1960 arasındaki atılım yıllarına geri dönmüştü. Sorunların hiçbiri, birinci maddedeki hükme haklı1ık kazandıracak boyutta değildi, komutanların radikal 9 Martçılara teveccüh edebilecek tabana, boş durulmadığı ve bir şeyler yapıldığ vermeye yönelik olarak hareket ettiği, olasılıkların en kuvvetlisi olarak durmaktaydi.

Türk milletinin ve sinesinden çıkan Silahl Kuvvetleri'nin bu vahim ortam hakkında duyduğu üzüntü ve ümitsizliğini giderecek çarelerin,

\footnotetext{
${ }^{96}$ Mehmet Ali Aybar, 12 Mart'tan Sonra [Meclis Konuşmaları], İstanbul: Sinan Yayınları, 1973.

${ }^{97}$ Ayrıntıların takibi için Arcayürek'in şu iki çalışması önemlidir: Cüneyt Arcayürek, Demirel Dönemi 12 Mart Darbesi 1965-1971 [Cüneyt Arcayürek Açıklıyor-5],

Ankara: Bilgi Yayınevi, 1985 a; Cüneyt Arcayürek, Çankaya'ya Giden Yol 1971-1973 [Cüneyt Arcayürek Açıklıyor-6], Ankara: Bilgi Yayınevi, 1985b.

${ }^{98}$ Olaylara başka bir cepheden bakan şu çalışma da önemlidir: Refik Sönmezsoy, Darbe [12 Mart Döneminde Türk İşçi Hareketi], İstanbul: Umur Kitapçılık, 1978.
} 


\begin{abstract}
partilerüstü bir anlayışla meclislerimizce değerlendirilerek mevcut anarşik durumu giderecek anayasanın öngördüğ̈̈ reformları Atatürkçü bir görüşle ele alacak ve inkllap kanunlarını uygulayacak kuvvetli ve inandırıcı bir hükümetin demokratik kurallar içinde teşkili zaruri görülmektedir.
\end{abstract}

Teşhis içeren ilk maddedeki tespitlerin arkasından gelen ikinci madde ise tedavi çarelerini son derece muğlak ifadelerle belirtiyor. Anayasanın öngördüğü reformlar tabiri bunun apaçık olanıdır. Demokratik, laik, sosyal hukuk devleti tabirlerinin; içinde toprak reformunu da bulunduran geniş bir yoruma tabi tutulabileceği gibi, devletin vatandaşını daha müreffeh bir yaşama kavuşturma yükümlülügünü yerine getirmiş olmasının kriterleri de göreceli ve bir o kadar tartışmaya açıktır. Birinci cümlede TSK'nin görev tanımı içine girmediği açık olan ve örgütlenmiş rekabetin içinden, yarışmacı bir sistem marifetiyle çıkan yürütme erkine yönelik görev gaspının söz konusu olduğu görülüyor. Toplumsal ve siyasal hayatın doğal sonucu olarak farklılaşan ve çatışan çıkarların ifadesi olan partileşmenin tabiatı dışına çıkılıp, partilerüstü şeklinde ifade edilen mecburi iş birliği dayatmasının ise ütopik oluşu, tartışmadan varestedir. Atatürkçü görüş tabiri ise kapsamı ve sınırları hâlâ tartışmalı bir meseledir. İnkılap kanunlarının bir dökümü yapılacak olursa, imza sahiplerinin bile önemli bir kısmını benimsemedikleri, yaşam somutlarında uygulamadıkları açıktır. Zaten bu maddeyle kendini bağlı hisseden komuta kademesi, CHP'li Nihat Erim'i önce istifa ettirip ve sonrasında bu isme birincisi teknokrat ağırlıklı; ikincisi, iki büyük partiden hiç de reformist olamayacak isimlerden müteşekkil iki hükümet kurdurmuştu. ${ }^{99}$ Erim isminin siyasal hayattan tasfiyesi de bu sürecin sonunda gerçekleşmiş, 12 Eylül arifesindeki suikasta kurban gidişi, başbakanlığı yıllarındaki uygulamalarıyla ilişkilendirilmişti. Ferit Melen ve ardından kurulan Naim Talu hükümetlerinin

\footnotetext{
${ }^{99}$ Ayrıntılar şu eserden takip edilebilir: Kurtul Altuğ, 12 Mart ve Nihat Erim Olayl, İstanbul: Baha Matbaas1, 1973. Hükümetler için bkz. Ahmet Gürkan, Cumhuriyet, Meclis, Hükümetler, Başkanlar 1919-1973 [27 Mayıs-12 Mart], Ankara: Güneş Matbaac1lık, 1973. Erim hükümetlerinde adeta, 12 Mart'ın sıkılmış yumruğu konumundaki, siyasi işlerden sorumlu başbakan yardımcısı Sadi Koçaş; 27 Mayıs-12 Mart sürekliliğini dört ciltte ayrıntılarıyla anlatır: Sadi Koçaş, Atatürk'ten 12 Mart'a, “Atatürk’ten 27 Mayıs'a”, [Anılar 1. Cilt], İstanbul: Tomurcuk Matbaas1, 1977a; Sadi Koçaş, Atatürk'ten 12 Mart'a, "27 Mayıs", [Anılar 2. Cilt], İstanbul: Tomurcuk Matbaas1, 1977b; Sadi Koçaş, Atatürk'ten 12 Mart'a "27 Mayıs'tan İkinci Cumhuriyet'e", [Anılar 3. Cilt], İstanbul: Tomurcuk Matbaası, 1977 c; Sadi Koçaş, Atatürk'ten 12 Mart'a "İkinci Cumhuriyet'ten 12 Mart'a", [Anular 4. Cilt], İstanbul: Tomurcuk Matbaası, 1977d.
} 
kaydettiği hiçbir başarı olmaması da zaten iki numaralı ihtarın geçersizliğini ortaya koymaktadır.

Bu husus süratle tahakkuk ettirilemediği takdirde,

Türk Silahl Kuvvetleri kanunların kendisine vermiş olduğu Türkiye Cumhuriyeti'ni korumak ve kollamak görevini yerine getirerek, idareyi doğrudan doğruya üzerine almaya kararlıdır. Bilgilerinize.

Son madde aslında net bir tehdit içermekte, doğrudan yönetimin ele alınabileceği; muhatapların parlamentonun açık bırakılabileceği seçeneklerinin olduğu gerçeğini gördükleri takdirde, olası dirençlerinin de bertaraf edilebileceği öngörüsüne dayanmıştır. Böylece ikinci maddede önce havuç, bu maddede ise tabiri caizse sopa gösteriliyordu. Klasik normlar hiyerarşisine tabi olmamakta kararlı asker, anayasaya referans vermek suretiyle aslında anayasal hükme sadakati gereği reform istiyor; anayasa dibacesinde yer alan baskıya karşı direnme hakkına değil, olası bir müdahale ihtimalinin yasal meşruiyetini yine ünlü iç hizmet kanununa dayanarak yapılacağının altını çizmiştir.

Muhtıra metnine yönelik olarak yaşanan dört sıcak saat içinde önce Demirel, Köşk'e ulaşmaya çalıştı ancak Sunay telefonlara çıkmadığı gibi herhangi bir şekilde temastan da kaçınmıştır. MiT Müsteşarı Korg. Fuat Doğu vasıtasıyla istifa etmesi telkininde bulunan Sunay; nihayet temas kurulduğunda, kendisinin de devreden çıkarıldığından bahisle, sağlık sebepleri gerekçe gösterilmek suretiyle görevden çekilmesini salık vermiş lakin Demirel böyle bir çekilişi de kabul etmemiş ve şu istifa mektubunu müsteşarının yardımcılarından biri vasıtasıyla ve mutadın dışında kuryeyle cumhurbaşkanına ulaştırmıştır ${ }^{100}$.

Cumhurbaşkanlı̆̆ı Yüksek Katına

Genel Kurmay Başkanı ve Kuvvet Komutanlarl tarafindan zat-ı devletlerinize, Cumhuriyet Senatosu Başkanlı̆̆ına ve Millet Meclisi Başkanlığına tevdi edilip, bugün saat 13 'teki radyo bültenlerinde Türk kamuoyuna da duyurulan MUHTIRA ILE ANAYASA VE HUKUK

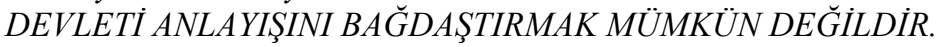

Bu durum muvacehesinde, hükümetin istifasını saygı ile arz ederim.

Başbakan Süleyman Demirel

\footnotetext{
${ }^{100}$ Demirel, 1977, s.147.Mehmed Kemal,12 Mart Öfkeli Generaller ve İşkence, İstanbul: Soyut Yayınları, 1974, s.22.
} 
Muhtıranın, iş başındaki AP ve dolayısıyla Demirel'e verildiği bir vakıadır ancak tek başına süreci açıklamaya kâfi değildir. Müdahaleyi meşru gösterecek olumsuzluklar aranmaya kalkıldığında, 12 Mart 1971 tarihi itibarıyla yaklaşık 48 yıllık cumhuriyetin belki de müdahaleye en uzak konumda olduğu söylenebilir. Yönetimde istikrarın değil, temsilde adaletin öne alındığı bir seçim sistemi yürürlüktedir hatta bu sistemin en aşırısı sayılabilecek olan milli bakiyeli model 1965 seçimlerinde tatbik edilmiş ve neredeyse hiçbir oy parlamentoda temsil dışı kalmamıştır. Böylesi bir sistemde yaklaşık yüzde 53 oy alan AP, millet meclisinde salt çoğunluktan sadece 14 sandalye fazlasıyla iktidar imkânı ancak bulabilmiştir. Bu da son derece kırılgan ve bunalımlara namzet bir iktidar süreci demektir; parti içi disiplinin son derece gevşek, milletin vekiliyle; partinin milletvekili olmak arasındaki dengeli çizgiden sapma arasındaki tereddüt ihtimali rizikosunun yüksek olması demektir.

\section{SONUÇ}

Türk siyasal hayatında, ordu-siyaset ilişkileri çoğu zaman bir uyum içinde olmamış; ordu bazı dönemlerde siyasete doğrudan darbe ya da kimi yasal ve anayasal yollarla sürekli müdahil olmuştur. $\mathrm{Bu}$ müdahaleler sonucunda Türkiye'de, çok partili demokratik hayatın bir süreliğine de olsa kesintiye uğramasıyla birlikte, Türk demokrasisi de ciddi anlamda zarar görmüştür. 12 Mart'ın, ordunun yönetime doğrudan el koymamasından dolayı müdahalelerin en serti olmaması fakat siyasi hayat ve sosyal yapı üzerinde derin etkiler bırakanı olduğu görülmektedir. 12 Mart'ın etkileri, özellikle ordu içine sızarak darbeye temayül eden kitlenin devşirilmesi suretiyle yakın dönemde bir kez daha nüksettiği anlaşılmaktadır.

Bilindiği üzere, Türkiye'de 27 Mayıs'tan 12 Mart'a kadar geçen süre ekonomik ve sınıfsal dönüşümlerin yaşandığ 1 bir dönemdir. 1960'l1 yıllar Türkiye'de siyasi alanda ciddi çekiş̧melerin olduğu ve istikrarın yakalanmadığ 1 bir süreçtir. $\mathrm{Bu}$ yıllarda siyasette ve ekonomide istikrarın bir türlü sağlanamaması, bir yandan büyük sanayicilerin tarım ve ticaret kesimleri karşısında hızlı bir şekilde büyümesine, diğer taraftan da ordunun doğrudan iktisadi olaylara müdahale etmesine ortam hazırlamıştır. Ayrıca bu yıllarda Türkiye'de hızlı bir biçimde politize olan işçi sınıfiyla gençliğin sınıfsal konumlarını aşan siyasal talepleri de dile getirmeye başlamaları hem ekonomik hem de politik mecranın bir çıkmaza doğru sürüklenmesine neden olmuştur. $\mathrm{Bu}$ durum, Türkiye'de siyasal sistemde tıkanmayla birlikte ekonomi ve siyasetin yeniden düzenlenmesini gerektirmiştir. Bu olayları yakından takip eden, söz konusu sorunların çözülemediğini ve sistemdeki tıkanıklıkların giderilmesi 
gerektiği iddiasında olan silahlı kuvvetler, 27 Mayıs'ta olduğu gibi 12 Mart'ta da yeniden siyasal işleyişe müdahil olmayı gerekli görmüştür.

Türkiye'de 27 Mayıs'tan 12 Mart'a kadar geçen süreç içerisinde Marksist sol, bilhassa üniversitelerde bir kısım öğrenciler, sanayi işçileri vasıtasıyla ve en önemlisi de sol görüşü benimseyen bazı aydınlar tarafindan yapılan propaganda aracılığıyla oldukça görünür ve tartışılır duruma gelmişti. Böylece belli bir sürecin sonu beklenmeden ve alelacele sosyalizmin Türkiye'de uygulamaya geçirilmesi istikametindeki ihtilalci metotların tatbiki beklentisi içinde olanlar, temelde orduya bu minvalde bakmışlardır. Üniversitelerde bu süreç içinde işgal ve boykotlara girişilmiş, aydınlar da basın yoluyla bu hareketleri desteklemişlerdir. Özellikle sınıf bilinci gelişmiş ağır sanayi işçileri çalıştıkları yerleri işgal etmişler ve grevler düzenlemişlerdir. Devrimci gençlik, attı̆̆ 1 Marksist sloganlarla ülkeye yeni bir düzen getirmek maksatl eylemlerin habercisi sayılabilecek siyasal eylemlere girişmeye başlamıştı. Ülke genelinde işçi ve öğrenci olaylarının yükseliş kaydetmesiyle ve TiP'in 1965 yılında ilk kez meclise girmesiyle birlikte yükselişin süreceği beklentisi hâkim olmuş ancak bu yükseliş uzun ömürlü olamamıştı. 1969 seçimlerinde Meclis'e bir önceki döneme göre önemli sandalye kaybıyla giren TİP hem parlamento dış1 sol muhalefetten hem de kendi içindeki tartışmalardan oldukça örselenmişti. Demokratik düzende sol bir iktidara olan teveccühün yetersiz olduğu görülmüş, bu durum öteden beri TíP ile metot sorunu içinde olan daha radikal sol çevrelere kısa süreli de olsa haklılık kazandırmıştı.

Müdahaleciler, 12 Mart öncesinde Türkiye'nin iki büyük partisi olan AP ile CHP'deki ciddi sorunların yarattı̆̆ zafiyetten de faydalanmıştı. Hem Demirel hem de İnönü parti içi muhalefetin yoğun baskısı altındaydılar, AP üstelik bölünmüş̧ü. Ordu içindeki sol ve Kemalist sol unsurlar eliyle düzenlenecek topyekûn bir darbenin sivil kanattaki işbirlikçilerinin güdümündeki uzun süreli örgütlenmenin kuvveden fiile geçme tarihi olarak saptanan 9 Mart 1971 tarihli hareketin, ordu hiyerarşisinden sapmayı da içeren boyut taşıması, komuta kademesinin en tepesindeki isimleri de karş1 eylemde bulunmaya sevk etmişti. 12 Mart'taki muhtıra bir taraftan mevcut hükümeti istifaya zorlarken diğer taraftan ordudaki dipten gelen dalgayı da teskin ediyordu. Muhtıranın üzerinden birkaç gün geçmişken ve henüz sözde partiler üstü hükümet kurulmamışken, bizzat Demirel'e imzalattırılan bir kararnameyle 9 Martçıların hemen her kademesindeki etkin isimler emekliye sevk ediliyorlardı.

12 Mart Muhtırası Türkiye'de kaybolan huzur ve güveni getiremediği gibi daha artırmış ve istikrarsızlığı derinleştirmişti. AP ve Demirel'in iktidardan uzaklaştırılma gerekçelerinden daha güçlü gerekçelerle meşruiyet yoksunluğuyla 
malul olan bu iki buçuk yıllık devrede ikisi Nihat Erim tarafindan olmak üzere Ferit Melen ve Naim Talu tarafindan kurulan hükümetler başarılı olamadılar. Tedhiş hareketleri artarak devam etti, insan hakları ihlalleri yapıldığına yönelik iddiaların ardı arkası kesilmedi, ekonomi kötü bir seyir izledi, vaat edilen reformların hiçbiri yapılmadığı gibi ülkenin onurlu dış politik tavrından kabul edilemez tavizler verildi. Ordunun hemen her kademesindeki hiyerarşik düzen altüst edildi. Sivil siyaset, 12 Mart'tan çıkış noktasında iki önemli tarihsel aşamayı kat etmek suretiyle nispi başarılar elde etti. İlki: Faruk Gürler'in empoze edilen cumhurbaşkanlığına mukavemet göstermek şeklinde temayüz ederken; ikincisi ise 14 Ekim 1973 seçimlerinde bizzat seçmen tarafından partilere 12 Mart sürecindeki tavırları nispetinde gösterilen teveccühle tezahür ediyordu.

\section{KAYNAKÇA / REFERENCES}

\section{ARȘIV BELGELERİ}

\section{CUMHURBAŞKANLIĞI CUMHURİYET ARŞIVİ (CCA)}

Fon Kodu:30.18.1.2; Yer No: 155. 1. 1.

Fon Kodu:30.1.0.0; Yer No: 54.329.2.

Fon Kodu:30.1.0.0; Yer No: 41.246.10.

Fon Kodu: 30.1.0.0; Yer No: 52.317.3.

Fon Kodu: 51.0.0.0; Yer No: 4.33.8.

Fon Kodu:30.1.0.0; Yer No: 128.819.6.

Fon Kodu:30.1.0.0; Yer No: 54.329.6.

Fon Kodu:30.1.0.0; Yer No: 48.284.2.

Fon Kodu:30.1.0.0; Yer No: 48.284.3.

Fon Kodu:30.18.2.2; Yer No: 286.62.6.

\section{ARAŞTIRMA VE İNCELEME ESERLERİ}

Ağaoğlu, S. (1965). Aşina Yüzler. Ağaoğlu Yayınevi.

Ağaoğlu, S. (1993). Siyasî Günlük [Demokrat Partinin Kuruluşu]. Yayına Haz. Cemil Koçak. İletişim Yayınları.

Ahmad, F. (1996). Demokrasi Sürecinde Türkiye, 1945-1980, (Çev. Ahmet Fethi). Hil Yayınları. 
Akdere, İ. \& Karadeniz, Z. (1994). Türkiye Solunun Eleştirel Tarihi-1. Evrensel Basım Yayım.

Aker, A. (1975). 12 Mart Döneminde Dışa Bă̆ımlı Tekelleşme. Sander Yayınları.

Akyaz, D. (2002). Askerî Müdahalelerin Orduya Etkisi: Hiyerarşi Dışı Örgütlenmeden Emir Komuta Zinciri. İletişi Yayınları.

Aldıkaçt1, O. (1973). Anayasa Hukukumuzun Gelişmesi ve 1961 Anayasası. İ̈ Yayınlarından No: 1850; HF Yayınları No: 413.

Altuğ, K. (1973). 12 Mart ve Nihat Erim Olayı. Baha Matbaası.

Altuğ, K. (1976). 27 Mayls'tan 12 Mart'a. Koza Yayınları.

Arcayürek, C. (1985a). Demirel Dönemi 12 Mart Darbesi 1965-1971 [Cüneyt Arcayürek Açıklıyor-5]. Bilgi Yayınevi.

Arcayürek, C. (1985b) Çankaya 'ya Giden Yol 1971-1973 [Cüneyt Arcayürek Açıklıyor-6]. Bilgi Yayınevi.

Aren, S. (1993). TIP Olayl [1961-1971]. Cem Yayınevi.

Atılgan, G. (2002). Yön-Devrim Hareketi [Kemalizm ile Marksizm Arasında Geleneksel Aydınlar]. TÜSTAV.

Avcıŏlu, D. (1971). Devrim Üzerine. Bilgi Yayınevi.

Aybar, M. A. (1973). 12 Mart'tan Sonra [Meclis Konuşmaları]. Sinan Yayınları.

Aybar, M. A. (1987). Neden Sosyalizm [Bir Son Sözle]. BDS Yayınları.

Aybar, M. A. (2014). Türkiye İş̧̧i Partisi Tarihi. Yay. Haz. Kıvanç Koçak. İletişim Yayınları.

Aydemir, Ş. S. (1976). İhtilâlin Mantı̆̆ı ve 27 Mayıs İhtilali. Remzi Kitabevi.

Aydemir, Ş. S. (tarihsiz). Menderes 'in Dramı? Remzi Kitabevi.

Aydemir, T. (1966). Ve Talat Aydemir Konuşuyor. May Yayınları.

Aydınoğlu, E. (1992). Türk Solu [Eleştirel Bir Tarih Denemesi 1960-1971]. Belge Yayınlar1.

Balcı, M. (1998). MGK ve Demokrasi [Hukuk-Ordu-Siyaset]. Yöneliş Yayınları. 
Başgil, A. F. (2006). 27 Mayıs Ihtilali ve Sebepleri-Görüp Yaşadıklarım. Çev. Cemal Aydın. Yağmur Yayınları.

Batur, M. (1985). Anılar ve Görüşler [Üç Dönemin Perde Arkas1]. Milliyet Yayınları.

Bayar, C. (1991). [Anlatan], Bir Darbenin Anatomisi [27 Mayıs İhtilali], Yazan: İsmet Bozdağ. Emre Yayınları.

Baykam, B. (1994). 27 Mayıs İlk Aşkımızdı. Ümit Yayıncılık.

Behram, N. (2005). Darağacında Ü̧̧ Fidan. Everest Yayınları.

Belli, M. (1966?). Milli Demokratik Devrim. Aydınlı Yayınları.

Belli, S. (1994). Boşuna mı Çiğnedik? [Anılar]. Belge Yayınları.

Bican, M. (1970). Devrim İçin Gençlik Hareketleri. Güvendi Matbaası.

Bilbilik, E. (2013). Öncesi ve Sonrastyla 9 Mart-12 Mart Süreci. Profil Yayıncilik.

Bilgiç, S. (2002). Hatıralar. Boğaziçi Yayınları.

Birand, M. A. Dündar, C. \& Çaplı, B. (1994). 12 Mart [İhtilâlin Pençesindeki Demokrasi]. İmge Kitabevi.

Bulut, F. (1995). Ordu ve Din [Asker Gözüyle İslamcı Faaliyetler]. Tümzamanlar Yayınc1lık.

Cem, İ. (1993). Tarih Açısından 12 Mart (Nedenleri, Yapısı, Sonuçları), [i̇ki Cilt Bir Arada]. Cem Yayınevi.

Cizre, Ü. (1994). AP-Ordu İlişkileri [Bir İkilemin Anatomisi]. İletişim Yayınları.

Çalışlar, O. (2007). Denizler İdama Giderken. Güncel Yayıncılık.

Çavdar, T. (2013). Türkiye'nin Demokrasi Tarihi 1950'den Günümüze, (5. Bask1). İmge Kitabevi.

Çelen, T. (2011). Denizler'den Terzi Fikri'ye Türkiye. İmge Kitabevi.

Çelen, T. \& Gürcan, Ö. (2006). 68 Gençliği ve Katledilişsi [Hesaplaşma]. Süvari Yayıncilik.

Çelikoğlu, A. (2010). Bir Darbeci Subayın Anıları [27 Mayıs Öncesi ve Sonras1]. YKY. 
Çobanl1, C. (2008). Mahir Deniz İbo [Anlatılan senin hikayendir]. Kalkedon Yayınları.

Demirel, H. (1977). 12 Mart'ın Íçyüzü [Nasıl Geldi, Nasıl Geçti?]. Yeni Asya Yayınları.

Demirel, T. (2021). Adalet Partisi [İdeoloji ve Politika]. İletişim Yayınları.

Demirel, T. (2021). Türkiye'nin Uzun On Yllı [Demokrat Parti iktidarı ve 27 Mayıs Darbesi]. Bilgi Üniversitesi Yayınları.

Demirer, M.A. (2012). 27 Mayıs [Masallar ve Gerçekler]. Toplumsal Yayıncılık Dilligil, T. (1966). (Sokaktaki Adam), Allahsız Gardiyan. Güneş Matbaacılık.

Dilligil, T. (1989). Imralı'da Üç Mezar. Dem Yayınları.

Dündar, C. (2014). Abim Deniz [Hiç yayınlanmamış mektup ve fotoğraflarla HAMDİ GEZMIŞ'in anıları]. Can Sanat Yayınları.

Elevli, A. (1960). Hürriyet İçin [27 Mayıs 1960 Devrimi]. Yeni Desen Matbaası

Elverdi, A. (1977). Bu Vatana Kastedenler [Ali Elverdi Paşa Anlatıyor]. Yeni Asya Yayınları.

Er, A. (2007). Hatıralarım ve Hayatım [27 Mayıs'tan 12 Eylül'e, Ahmet Yesevi'den Yunus Emre'ye]. Pamuk Yayıncilık.

Erdoğan, M. (1990). Silahlı kuvvetlerin Türk Anayasa düzeni içerisindeki yeri. Ankara Üniversitesi SBF Dergisi, 45/1 (1990), 309-334.

Eren, M. (1996). 27-28 Nisan 1960 Gençlik Eylemi Işı̆̆ı̆nda 27 Mayıs. Yazarın Kendi Yayını.

Erkanlı, O. (1973). Anılar ... Sorunlar ... Sorumlular. Baha Matbaası.

Erkanlı, O. (1987). Askeri Demokrasi [Orhan Erkanlı'nın Anıları 1960-1980]. Güneş Yayınları.

Eroğlu, E. (1974). 12 Mart Devam Ediyor mu? Soyut Yayınları.

Ersan, V. (2014). 1970'lerde Türkiye Solu. İletişim Yayınları.

Esengin, K. (1978). 27 Mayls ve Ordudaki Kıyımlar [Ordudaki Emeklilik Olayı]. Su Yayınları.

Esin, N. (2005). Devrim ve Demokrasi [Bir 27 Mayısçının Anıları]. Doğan Kitapçılık AŞ.

Feyizoğlu, T. (2000). Deniz [Bir İsyancının İzleri]. Su Yayınları. 
Feyizoğlu, T. (2011). Denizler ve Filistin. Alfa Basım Yayım.

Feyizoğlu, T. (2015). FKF Fikir Kulüpleri Federasyonu [Demokrasi Mücadelesinde Sosyalist Bir Öğrenci Hareketi]. Ozan Yayıncılık.

Genç, S. (1971). 12 Mart'a Nasıl Gelindi? İleri Yayınları.

Gevgilili, A. (1973). Türkiye'de 1971 Rejimi [Tarım Toplumundan Sanayi Toplumuna Geçiş Aşaması]. Milliyet Yayınları.

Gevgilili, A. (1981). Yükseliş ve Düşüş. Altın Kitaplar Yayınları.

Gevgilili, A. (1989). Türkiye'de Kapitalizmin Gelişmesi ve Sosyal Sınıflar. Bağlam Yayınları.

Günel, Y. (1960). Seçkin Devrim [19 Mayıs'tan 27 Mayıs'a]. Devrimleri Koruma ve Yayma Derneği Yayını.

Gürcan, Ö. (2005), Ben İhtilâlciyim [Fethi Gürcan]. Süvari Yayıncılık.

Gürcan, Ö. (2005). Fethi Gürcan'ın Harbiyelileri. İleri Yayınları.

Gürkan, A. (1973). Cumhuriyet, Meclis, Hükümetler, Başkanlar 1919-1973 [27 Mayıs-12 Mart]. Güneş Matbaacılık.

Gürkan, C. (1986). 12 Mart'a Beş Kala. Tekin Yayınevi.

Hale, W. (1996). Türkiye'de Ordu ve Siyaset 1789'dan Günümüze, (Çev. Ahmet Fethi). Hil Yayınları.

Harris, G. S. (1979). Türkiye'de Komünizmin Kaynakları, çev. Enis Yedek. Boğaziçi Yayınları.

Hasan Cemal (1999). Kimse Kızmasın Kendimi Yazdım. Doğan Kitap.

Hekimoğlu, M. (1975). 27 Mayıs’ın Romanı. Çağdaş Yayınları.

Ilıcak, N. (1975). 15 Yll Sonra 27 Mayıs Yargilaniyor-2. Kervan Yayınları.

Ilıcak, N. (1977). 15 Yll Sonra 27 Mayls Yargllanıyor-1. Kervan Yayınları.

Ilıcak, N. (2001). 12 Mart Cuntaları [Demokrasinin Sırtındaki Hançer]. TIMASŞ Yayınları.

İpekçi, A. \& Coşar, Ö.S. (1965). İhtilalin İçyüzü. BATEŞ Dağıtım.

İsen, C. K. (1964). Geliyorum Diyen Ihtilal [22 Şubat-21 Mayıs]. Tan Gazetesi ve Matbaasi. 
İsmail, C. (1993). Tarih Açısından 12 Mart (Nedenleri, Yapısı, Sonuçları), [ìki Cilt Bir Arada]. Cem Yayınevi.

Kalpakçıŏlu, Ö. (1969). İkinci Cumhuriyetin 3 Başbakanı ve Olaylar-III [İnönü-Ürgüplü-Demirel]. Nüve Matbaas1.

Kara, M. A. (2004). Demokrasi ve Uzlaşma Kültürü Açısından Koalisyonlar [Türk Siyasal Yaşamında 1961 Sonrası Bir Olgu]. Otopsi Yayınları.

Kara, M. A. (2008). Yön'ün Devrimi Devrim'in Yönü. Cumhuriyet Kitaplar1.

Karadeniz, H. (1975). Olaylı Yıllar ve Gençlik. May Yayınları.

Karavelioğlu, K. (2007). Bir Devrim İki Darbe [27 Mayıs, 12 Mart, 12 Eylül]. Gürer Yayınları.

Karpat, H. K. (2010). Türk Demokrasi Tarihi,(Yayın Yönetmeni: Emine Eroğlu). Timaş Yayınları.

Kaynak, M. (2003). Yel Üfürdü Su Götürdü: Ailem, Çocukluğum, Gençliğim, Mesleğim, Yaşadıklarım ve Gördüklerim... Babıali Kültür Yayıncılığı.

Kayal1, K. (1994). Ordu ve Siyaset [27 Mayıs-12 Mart]. İletişim Yayınları.

Kemal. M. (1974). 12 Mart Öfkeli Generaller ve İskence. Soyut Yayınları.

Kıvılcımlı, H. (1970). 27 Mayıs ve Yön Hareketinin Sinıfsal Eleştirisi. Ant Yayınları.

Kili, S. (1998). 27 Mayls 1960 Devrimi Kurucu Meclis ve 1961 Anayasast. Boyut Kitaplar1.

Koçaş, S. (1977a). Atatürk'ten 12 Mart'a, “Atatürk'ten 27 Mayıs'a”, [Anılar 1. Cilt]. Tomurcuk Matbaası.

Koçaş, S. (1977b). Atatürk'ten 12 Mart'a, "27 Mayıs", [Anılar 2. Cilt]. Tomurcuk Matbaası.

Koçaş, S. (1977c). Atatürk'ten 12 Mart'a "27 Mayıs'tan İkinci Cumhuriyet'e", [Anilar 3. Cilt]. Tomurcuk Matbaasi.

Koçaş, S. (1977d). Atatürk'ten 12 Mart'a "İkinci Cumhuriyet'ten 12 Mart'a", [Anilar 4. Cilt]. Tomurcuk Matbaas1.

Kuray, S. (2008). İsyan ve Tevekkül. Birharf Yayınları.

Küçük, S. (2008). Rumeli'den 27 Mayıs'a [İhtilalin Kaderini Belirleyen Köşk Harekât1]. Mikado Yayınları. 
Küçük, Y. (1988). İtirafçıların İtirafları [TKP Pişmanları]. Tekin Yayınları.

Lewis, B. (1993). Modern Türkiye'nin Doğuşu, (Çev. Metin Kıratl1), (5. Bask1). Türk Tarih Kurumu Yayınlar1.

Marx, K. (2015). Kapital [Ekonomi Politiğin Eleştirisi], (Sermayenin Üretim Süreci), Cilt 1, çev. M. Selik-N. Satlıgan. Yordam Kitap.

Öner, M. (2017). Deniz [Devrimcinin İşi Devrim Yapmaktır]. Ceylan Yayınları. Örtülü, E. (1966). ÜÇ İhtilâlin Hikâyesi. Milli Ülkü Yayınevi.

Öymen, Ö. (1987). Bir İhtilâl Daha Var... 1908-1980. Milliyet Yayınları.

Öz, E. (1976). Deniz Gezmiş Anlatıyor. Cem Yayınevi.

Özdemir, H. (1993a). Sol Kemalizm. İz Yayınc1lık.

Özdemir, H. (1993b). Türkiye Cumhuriyeti’nde Rejim ve Asker Iliş̧kisi Üzerine Bir İnceleme. İz Yayıncıl1k.

Özdemir, H. (1994). Cumhurbaşkanlı̆̆ Seçimlerinde Ordunun Olağandışı Rolü [Türkiye Örneği]. İz Yayınc1lık.

Özdemir, H. (1995). Türkiye Cumhuriyeti. İz Yayıncılık.

Özgün, Y. (2003). 27 Mayıs Dönemi Demokrasi Söylemi. Yayımlanmamış doktora tezi. AÜ SBE.

Özkaya, Ş. (2005). Adım Adım 27 Mayıs. İleri Yayınları.

Öztuna, Y. \& Gökdemir, A. (1987). Türkiye'de Askeri Müdahaleler. Tercüman Yayınları.

Perin, M. (1970). Yassıada ve İnfazların İçüzü. M. Çevik Matbaası.

Perin, M. (1990). Yassiada Faciası (27 Mayıs Darbesinden İdamlara Kadar İşkence Altında Ezilenlerin Dramı), C-1. Dem Yayınları.

Sağıroğlu, H. Vd. (1961). Hürriyet Meşalesi [27 Mayıs Milli Türk İhtilali]. MTTB, İstanbul Üniversitesi İktisat Fakültesi Talebe Derneği Yayınları.

Sanal, T. (1995). Türkiye Cumhuriyeti ve 50 Hükümeti. Sim Matbaac1lık.

Sarıül, N. (2001). 27 Mayls ve Talat Aydemir'in Darbe Girişimleri (22 Şubat 1962 ve 21 Mayıs 1963). Yayımlanmamış yüksek lisans tezi, AÜ SBE.

Savaşçı, O. (2015). Cepheden Anılar [Orhan Savaşçı'nın THKP-C Anıları]. Ayrıntı Yayınları. 
Seyhan, D. (1966). Gölgedeki Adam. Uycan Matbaası.

Sönmezsoy, R. (1978). Darbe [12 Mart Döneminde Türk İşçi Hareketi]. Umur Kitapçılık.

Sunay, C. (2017). 27 Mayıs'tan 13 Kasım'a Milli Birlik Komitesi. Ohri: Social and Cultural Integration in Balkans, International Vision University.

Sülker, K. (1980). Türkiye’yi Sarsan İki Uzun Gün [Belgesel]. Yazko.

Şener, M. (2015). Türkiye Solunda Ü̧̧ Tarz-ı Siyaset [Yön, MDD ve TIP]. Yordam Kitap.

Tanör, B. (1994). Íki Anayasa [1961 ve 1982]. Beta.

Tanör, B. (2006). Osmanlı-Türk Anayasal Gelişmeleri, (26. Baskı). Yapı Kredi Yayınları.

Taylak, M. (1994). 27 Mayıs ve Türkeş. Hamle Yayınları.

Toker, M. (1992). Inönü’nün Son Başbakanllğı 1961-1965 [Demokrasimizin İsmet Paşalı Yılları 1944-1973]. Bilgi Yayınevi.

Toker, R. Ü. (1960). Inkılâp Mevzuatı: Teşkilâtı Esasiye Kanunu ile Tadili Hakkında Geçici Kanun [27 Mayıs 1960 Tarihinden İtibaren Vazedilen Kanunlar- Millı̂ Birlik Komitesi Kararları - Tüzükler]. Becid Basımevi.

Torcu, L. (1994). Demokrat Parti'yi 27 Mayls'a Götüren Nedenler. Yayımlanmamış yüksek lisans tezi. DEÜ AIİTE.

Tufan, T. (2007). Deniz [Firtınalı Y1llar]. Nokta Kitap.

Tunç, B. (2020).Türk Anayasa tarihinde 1961 Anayasası'nın yeri ve önemi. Karadeniz Araştırmaları Merkezi Dergisi, 17/67, 657-692.

Tunçkanat, H. (1996). 27 Mayls 1960 Devrimi [Diktadan Demokrasiye]. Çağdaş Yayınları.

Turgut, M. (1990). Siyasetten Portreler. Boğaziçi Yayınları.

Turhan, H. (2011). Che Guevara-Deniz Gezmiş-Bir Dava İki Devrimci [Unutmak İhanettir]. Güz Yayınları.

Turhan, H. (2012). Deniz Gezmiş [Unutmak İhanettir]. Güz Yayınları.

Türkeş, A. (1996). 27 Mayıs, 13 Kasım, 21 Mayıs ve Gerçekler. Hamle Basın Yayın. 
Uçar, F. (2019). Türk Siyasi Hayatında Azınlık Hükümetleri [İnönü ve Demirel Dönemleri]. Berikan Yayınevi.

Uçar, F. (2021). Türk Siyasi Hayatında Milliyetçi Cephe Hükümetleri, 2. Bask1. Berikan Yayınevi.

Ulay, S. (1968). (General Sıtkı Ulay'ın Hatıraları), "Harbiye Silâh Başına!", [27 May1s 1960]. AR Matbaas1.

Ulay, S. (1996). Giderayak. Milliyet Yayınları.

Ünsal, A. (1980). Siyaset ve Anayasa Mahkemesi [Siyasal Sistem Teorisi Açısından Türk Anayasa Mahkemesi]. AÜSBF Yayınları No: 443.

Varlık, Ü.ve Ören, B. (2001). Seçim Sistemleri ve Türkiye'de Seçimler. Der Yayınları.

Vural, H. (1960). Hürriyet Savaşımız. Mete Matbaası.

Yalçın, S. (1994). Hangi Erbakan. Başak Yayınları.

Yetkin, Ç. (1970). Türkiye'de Soldaki Bölünmeler 1960-1970 [Tartışmalar, Nedenler, Çözüm Önerileri]. Toplum Yayınları.

Yetkin, Ç. (1998). 12 Mart 1971 Öncesinde Türkiye'de Soldaki Bölünmeler. Toplumsal Dönüşüm Yayınları.

Yıldırım, A. (2008). FKF Dev-Genç Tarihi [1964-1971 belgeleriyle bir dönemin serüveni]. Doruk Yayınları.

Yıldırım, A. (2011). Deniz Gezmiş’ ’in Günlügüu. Yol Bilim Kültür Araştırma.

Y1lmaz, V. (2009). Emirle Gelen İdam Kararı. Tümzamanlar Yayıncılık.

Zürcher, E. J. (2000). Modernleşen Türkiye'nin Tarihi, (Çev. Yasemin Saner), (7. Baskı). İletişim Yayınları.

\section{EXTENDED ABSTRACT}

Turkish military memorandum, issued on March 12, 1971, is one of the milestones of Turkish political life. The disclosures, that had some raging aspects, and that were flourished with sorrowful heroism mouth that the intelligentsia identified all along only with the execution of three left-winger young persons, or on the contrary that were bringing forward their motive of treason, are intensifying the mystery behind the incident more. Along with the disclosures in the direction that only the internal dynamics were present behind the incident, 
degrading the external dynamics only to the imperialism of USA is not satisfying enough. Along with presenting the American interference behind the formation and activities of governments of memorandum period and of the interim period following it, it is being observed again such circles propounded the propaganda that the government eliminated by the memorandum was Americanizer.

Along with the tendency of interference, sometimes constituting a contradiction with the dependence on hierarchy in the chain of command of Turkish army, the passion of finding top brass, by the expression of May 27, for the top of operation even if seemingly, as it was important for ensuring unity and solidarity in the coup to be attempted, also pushed March 09 to a conclusion whose end would be defeat. Celil Gürkan was a major general, and Vedii Bilget was radm, and the other names were ranking as brigadier general. Erol Bilbilik, who was low in rank, but who was one of the significant names of March 09, was lieutenant commander, and Sarp Kuray and Ali Kurca, who were then at the fore as two commissioned officers with the lowest rank in the base, were just lieutenants at that time. It can be said that it caused the two names at the top, Faruk Gürler, who was elected as the commander of Turkish armed forces in 1972 following the memorandum of March 12, and Muhsin Batur, with the concern that they were being considered in the Gürsel model of May 27, and that they would first be made nonfunctional and then would be discharged, to make -instead of radical coup such as March 09- the move such as March 12 both softening the stress on the base and enabling minimum satisfaction at the point that something was being made against the government and enabling the discharge of the radical group supporting March 09.

It can be said that the main reason of March 12 is actually hidden in the protocol signed on October 21, 1961 by the Istanbul and Ankara groups of Armed Forces Association's junta upon the shock caused by the election results of October 15 . In the text of the referred protocol, the anger against the electors was implicitly present due to low number of votes received by the power behind May 27, namely by CHP. The result obtained in the voting of 1961 Constitution actually lit a signal flare regarding the consequence of the election results of October 15, but still the hesitation regarding that $\mathrm{CHP}$ would come to the power alone as exceeding 40 percent in the elections of 1957 was very low. And even it is narrated that Inönü said that "they shouldn't get involved in such things, CHP will definitely win the elections" towards the coup plotters reaching him traveler the intermediacy of Faik Ahmet Barutçu. The nature of the new constitution, which was creating various autonomous institutions while making the enforcement passive, the inspection or support of the winning political party through supreme boards as per its spirit, and the election system on top of it weakened the possibility of a 
single party, especially CHP, to come to the power. The aim was to establish constitutional mechanisms which would restrain the conservative right government, which was possible to be elected as it was observed in the elections of 1965, rather than a strong CHP government. Hence, such mechanisms, which would be maintained until September 12, were strengthened more by the constitutional regulations made after March 12. A brief evaluation over the full text of the memorandum would actually show the groundlessness of the reasons of legitimacy.

The memorandum of March 12 was of course written as addressing the then current government, but when its practices and executions against the sections, supporting it in the beginning, are considered, the profile of ones that it deemed as opponent was very extensive, and the distance of its opponents with USA was very far. In this sense, it is required to briefly urge upon the claims that didn't consort with the reasons in the content of the memorandum, and upon the tendency of imposing on the civilians the responsibility in matters neglected in being solved. Above all, it is being known that, especially after May 27, the message that "civil government is being supported" was given against the two attempted military coups that was subject to the equation of CHP + Army $=$ Power, and if not revolution, and that occurred against İnönü and his political party. Between years 1961-1965, despite the dominance of the mindset of May 27 , it seems as if like apparent that the opportunities, regarding the practice of reforms anticipated by the constitution, were wasted. Though, the bed of nails of AP Government, that came to the power in 1965, and that was obliged to observe the sensitive balance between not making the armed forces afraid and pursuing its practices with ultimate care, was not highlighted.

It is a fact that the memorandum was presented to AP and thus to Demirel, but it is not enough to explain the process by itself. When negative facts, that would show the interference legitimate, are sought, it can be said that the republic, of about 48 years by March 12,1971, was actually at the most distant position for interference. And election system, in which not the stability of government, but justice in representation was being brought forward, was in force, and even the national remainder model, which may be deemed as the most radical incidence of that system, was applied in the elections of 1965, and nearly no votes remained unrepresented at the parliament. AP, that received 53 percent of the votes in such a system, could just had the opportunity of being the power by only 14 chairs more than the absolute majority. And that implied an extremely fragile process of power subject to crises; and also implied extremely loose discipline within the political party, and high risk of deviating from the balanced line between being the deputy of nation and the deputy of the political party. 